\title{
Application of advanced technologies in landslide research in the area of the City of Zagreb (Croatia, Europe)
}

\author{
Snježana Mihalić Arbanas, Martin Krkač and Sanja Bernat
}

University of Zagreb, Faculty of Mining, Geology and Petroleum Engineering, Pierottijeva 6, Zagreb, Croatia; (corresponding author: smihalic@rgn.hr)

doi: $10.4154 / g c .2016 .18$

\section{Article history:}

Manuscript received October 21, 2015 Revised manuscript accepted April 17, 2016 Available online June 28, 2016
Keywords: landslide identification, landslide mapping, landslide monitoring, Kostanjek landslide, Podsljeme Zone, City of Zagreb

\begin{abstract}
This paper describes the application of advanced technologies for landslide detection, mapping and monitoring in the City of Zagreb since 2010. Airborne Light Detection and Ranging (LiDAR) data are used to visually identify landslides in the Podsljeme Zone over an area of $180 \mathrm{~km}^{2}$ for the purpose of landslide inventory mapping. The total number of landslides in the analyzed area (approx. 1,600 landslides) is estimated based on the average landslide density ( 9 landslides per square $\mathrm{km}$ ) from the most reliable geomorphological historical inventory produced in 1979. Examples of the visual interpretation of very-high-resolution bare-earth DEMs (Digital Elevation Model) are given to show the potential of these advanced techniques to identify the landslide contours of the very small, small and moderately small landslides that are characteristic of the study area, which is composed of engineering soils and/or soft rocks (marls). In the framework of the described landslide research, the biggest landslide in the Podsljeme Zone, the Kostanjek landslide (landslide area of $1 \mathrm{~km}^{2}$ ), was also equipped with an automated near-real time monitoring system that encompassed approximately 40 sensors to monitor landslide movement and landslide causal factors. Monitoring of this deep and large landslide during multiple extreme hydro-meteorological events from January 2013 to January 2015 enabled collection of data for the analysis of landslide movement both on and below the surface as well as analysis of the relationship between landslide reactivations and their triggers, i.e., changes in groundwater level and precipitation. The final aim of the described scientific research in terms of landslide mapping and monitoring is its practical application in land-use planning and civil protection systems in the City of Zagreb. Namely, the conclusions propose reliable and efficient methods for landslide identification and monitoring, which are necessary to provide data and solutions for hazard and risk reduction to local authorities that are managed by the City.
\end{abstract}

\section{INTRODUCTION}

A "landslide" is the movement of a mass of rock, debris, or earth down a slope under the influence of gravity (CRUDEN \& VARNES, 1996). Here, the terms "landslide", "mass movement", and "slope failure" are used as synonyms. MIHALIĆ ARBANAS \& ARBANAS (2014) divided landslide research into five broad categories: landslide identification and mapping, landslide investigation, landslide monitoring, landslide hazard and risk assessment, and landslide stabilization and remediation measures.

The application of advanced technologies for landslide identification, mapping and monitoring in the area of the City of Zagreb in Croatia began in 2010 in the framework of the bilateral scientific Japanese-Croatian SATREPS FY2008 project 'Risk Identification and Land-Use Planning for Disaster Mitigation of Landslides and Floods in Croatia' (MIHALIĆ \& ARBANAS, 2012). The implementation of the project's activities in the continental part of Croatia encompassed (i) the identification and mapping of landslides in the southern and south-eastern hills of Medvednica Mt., which belongs to the City of Zagreb; and (ii) monitoring of the deep-seated Kostanjek landslide, located in the western part of the hilly area, in an urban part of the City of Zagreb. Figure 1. depicts the study area for the inventory mapping, with a total area of $180 \mathrm{~km}^{2}$ as indicated by the red line, and the location of the monitored Kostanjek landslide, indicated by the red dot.

Because of its geomorphological and geostructural position, the area of the City of Zagreb is located in the western mega-geo- morphological region of the European Pannonian Basin in NW Croatia (PAVELIĆ et al., 2003). The city covers an area of $640 \mathrm{~km}^{2}$ and includes the urban area (Zagreb City) and 69 settlements with approx. 800,000 residents ( $\sim 18 \%$ of the population of Croatia). The urbanized area $\left(220 \mathrm{~km}^{2}\right)$ is located below the forest region of Medvednica Mt. to the north and extends to the flood plain of the Sava River to the south (Fig. 1). The climate is continental with a mild maritime influence and a mean annual precipitation (MAP) of $883.6 \mathrm{~mm}$ (BERNAT et al., 2014).

The hills in the northern part of the County (known as the Podsljeme Zone) were chosen as the study area because $32 \%$ of Zagreb City belongs to this area. Moreover, this area is very attractive as a residential zone with a continuously increasing population density and intensifying construction activities with the enlargement of the area of built-up land. One of the oldest property damage records from a particular landslide in the Podsljeme area dates from 1925 (FIJEMBER, 1942). Although measures have been taken in the City of Zagreb to promote land use, development and construction practices that do not exacerbate the landslide problem, the relative proportion of artificially caused landslides from urbanization of the hilly zone have been continuously increasing over the last 90 years (POLAK et al., 1971; ŠIKIĆ et al., 1984; CESAREC \& POLAK, 1986; JURAK et al., 1996, 1998; SOKOLIĆ et al., 2006).

The Kostanjek landslide is one of numerous landslides within the borders of the study area but is specific according to its size, as interpreted by ORTOLAN (1996) and STANIĆ \& 


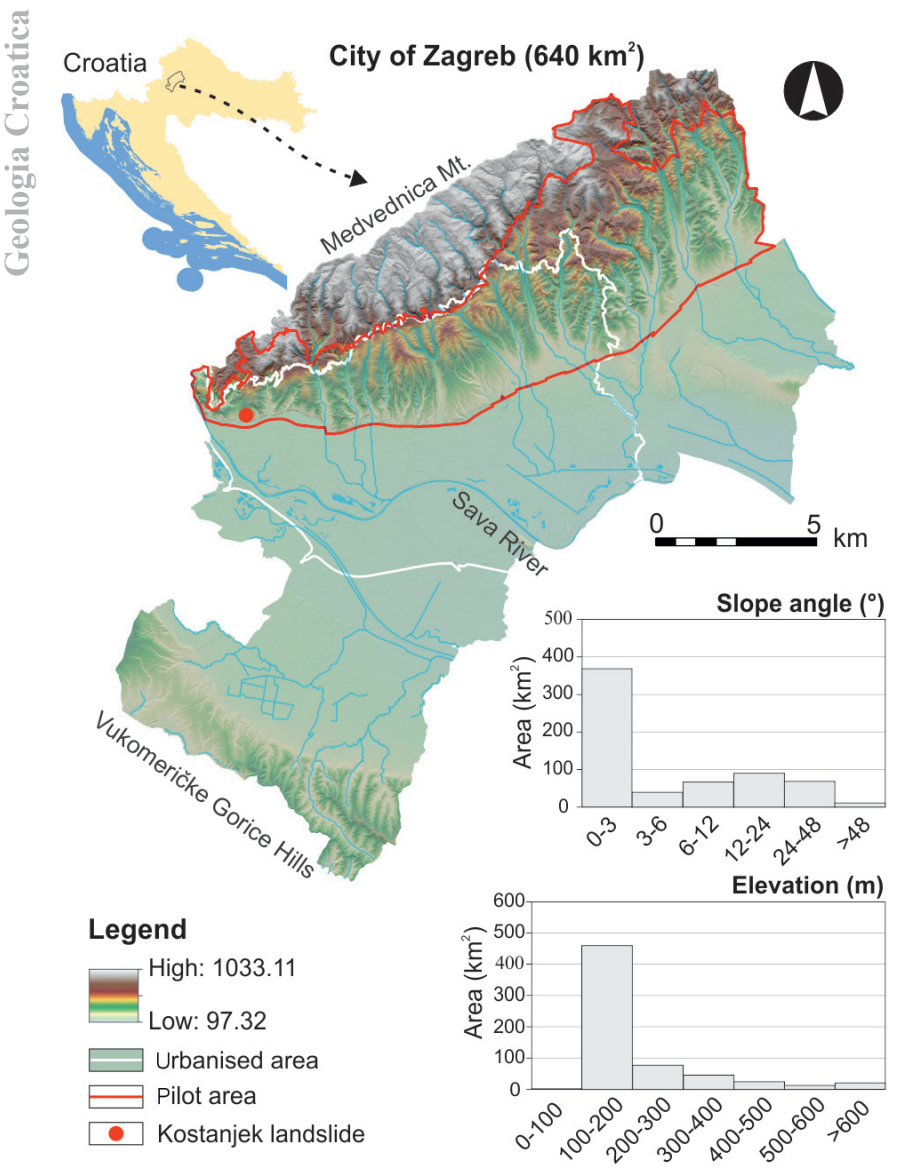

Figure 1. Relief map of the City of Zagreb with histograms that show the frequency of elevations and slope angles as computed from a 2-m resolution DEM for the whole area. The urbanized area, i.e., Zagreb City, the border of the Croatian-Japanese SATREPS FY2008 project's pilot area and the location of the Kostanjek landslide are also indicated.

NONVEILLER (1996): the landslide volume is $32.6 \times 10^{6} \mathrm{~m}^{3}$ and the depth of displaced mass is $90 \mathrm{~m}$. The landslide activity over the last 50 years has completely stopped urban planning and development in the approximate $1 \mathrm{~km}^{2}$ area of the Kostanjek landslide. Construction of new apartment buildings in this residential area is forbidden, and existing houses and structures require repeated remediation. The local authorities from the City of Zagreb must find cost-effective solutions for this human and environmental threat. Potential hazards in the form of large movements of reactivated landslide can become disastrous because there are approximately 290 endangered buildings on the landslide surface.

Identifying and mapping landslides in the area of Medvednica Mt. included landslide inventory mapping based on remote sensing methodologies that were defined in GUZZETTI et al. (2012). One of the tasks was to find appropriate technologies to determine landslide boundaries of very small to moderately large landslides (primarily $<10,000 \mathrm{~m}^{2}$ ) that are mostly covered by deciduous vegetation and partially masked by urbanization. Part of the aforementioned project activities was also the identification and mapping of landslides using visual interpretation of historical stereoscopic aerial photographs. PODOLSZKI (2014) estimated the reliability of identified landslides in the study area in Zagreb by this conventional technique, which ranged from $32 \%$ to $49 \%$ depending on the scale of the interpreted photographs. The advanced method that was applied in the study area was an analysis of the surface morphology of very-high-resolution (1-m resolution) digital elevation models (DEMs) that were captured by airborne LiDAR (Light Detection and Ranging) in 2011 and 2013 (MIHALIĆ et al., 2013). Examples from the literature reveal that previous investigators used 5-m resolution DEM (VAN den EECKHAUT et al., 2007), 2-m resolution DEMs (ARDIZZONE et al., 2007), 1.8-m resolution DEMs (SCHULZ, 2007), or 1-m resolution DEMs (McKEAN \& ROERING, 2004; ĐOMLIJA et al., 2014) for the purpose of landslide inventory mapping.

An integrated automated monitoring system of the Kostanjek landslide (the Kostanjek Landslide Observatory) was established from 2011 to 2013 in the framework of the Japanese-Croatian project (KRKAČ et al., 2013; 2014b). The objective of the monitoring system was to continuously observe the parameters of landslide movement in real-time and monitor the landslide's causal factors, i.e., processes that trigger landslide reactivations, such as precipitation, groundwater changes and earthquakes (KRKAČ et al., 2014a). Continuous data series that were collected by sensor networks enable the analysis of landslide movement and its causes and the analysis of the interrelations between the dynamics of landslide and causal processes. Integrated monitoring systems are usually established at landslides for long-term landslide monitoring, which presents high risks for particular societies. Examples of landslides that are equipped with integrated monitoring systems include Ancona (COTECCHIA, 2006), Corvara (CORSINI et al., 2005), Tessina (PETLEY et al., 2005) and Valoria (CASTAGNETTI et al., 2013) in Italy; Gradenbach in Austria (BRÜCKL et al., 2006); Åknes in Norway (BLIKRA, 2012); Turtle Mountain in Canada (FROESE et al., 2012); and Grohovo in Croatia (ARBANAS et al., 2012).

The following sections briefly describe the study areas (the Podsljeme Zone and the Kostanjek landslide) with summarized overviews of historical data related to landslide events. This section is followed by a short overview of applied advanced technologies, research methods and the main results. After discussing the potential advantages and the current limitations of these new methodologies, the conclusions present a perspective on the future production and use of landslide inventory maps of the entire Podsljeme Zone area and the future analysis and application of continuous observations of the Kostanjek landslide to the prognosis of landslide hazard and risk.

\section{LANDSLIDE INVENTORY MAPPING}

\subsection{Study area}

The hilly area in the southern foothills of Medvednica Mt., which has an area of $180 \mathrm{~km}^{2}$, is highly urbanized and densely populated (BELIĆ et al., 2014). The elevations in this area range from 115 to $612 \mathrm{~m}$ a.s.l., the prevailing slope angles (59\%) are from $6^{\circ}-24^{\circ}$ and $84 \%$ of the slopes have slope angles $>3^{\circ}$, which are potentially prone to sliding. The dominant types of slope movements are small and shallow landslides that mostly endanger residential structures and roads (MIHALINEC \& ORTOLAN, 2008), especially after intensive precipitation events, such as those that are analyzed in BERNAT et al. (2015) for the period 2010-2015. Figure 2 shows typical damaged roads and houses in the winter of 2013 in Zagreb.

The study area is composed of Upper Miocene and Quaternary sediments (ŠIKIĆ, 1995), as shown in Fig. 3. The Upper Miocene deposits are stratified sands, silts and marls, with moderately to slightly inclined bedding and bedding slope angles that range from $10^{\circ}-20^{\circ}$ (AVANIĆ et al., 2003; VRSALJKO et al., 2006). The upper parts of the Miocene deposits are fine-grained soils, mostly silts. The Quaternary deposits are heterogeneous 


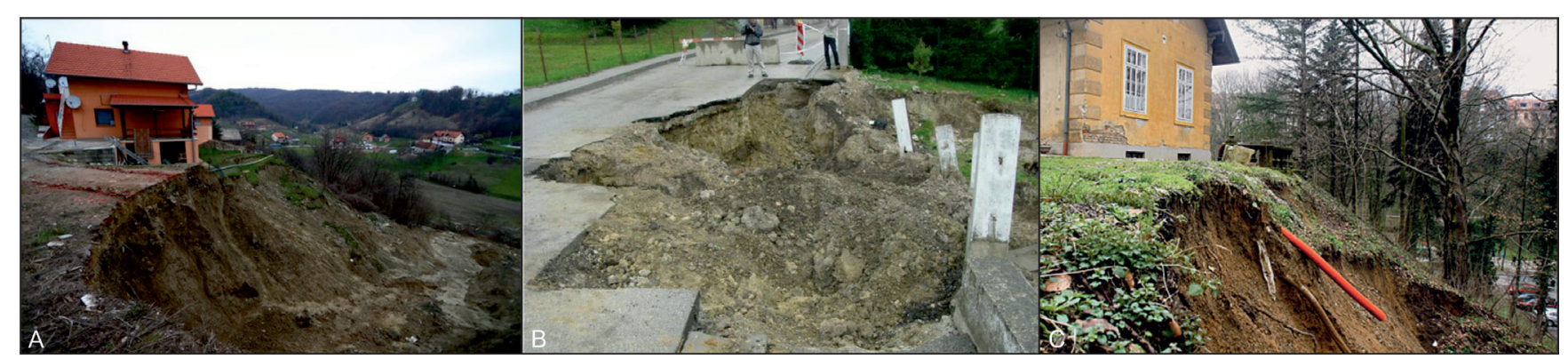

Figure 2. Examples of landslides endangering/damaging houses or public roads in the winter of 2013 in Zagreb: (A) Lazina landslide; (B) Šestinski Dol landslide; (C) Dubravkin Put landslide.
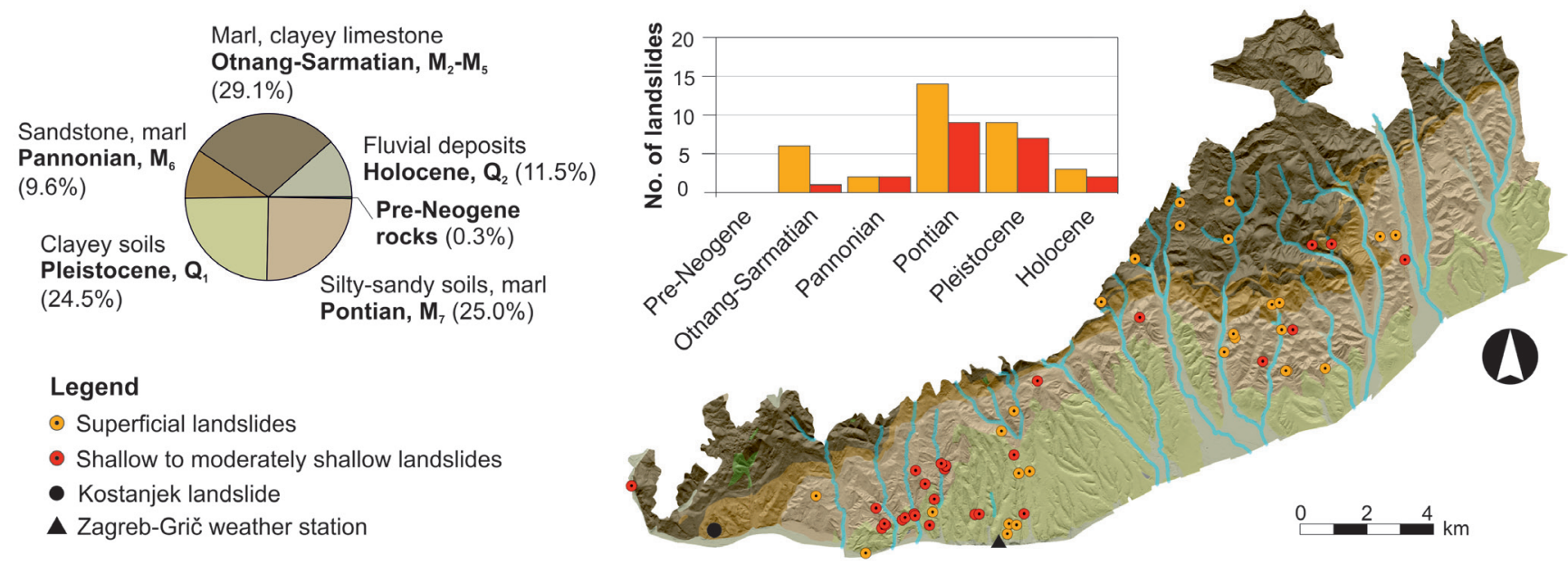

Figure 3. Precipitation-triggered landslide inventory map for the period from 1st January to 7th April 2013. The pie chart shows the relative distribution of the main stratigraphic units; the histogram shows the number of (re)activated landslides per stratigraphic unit.

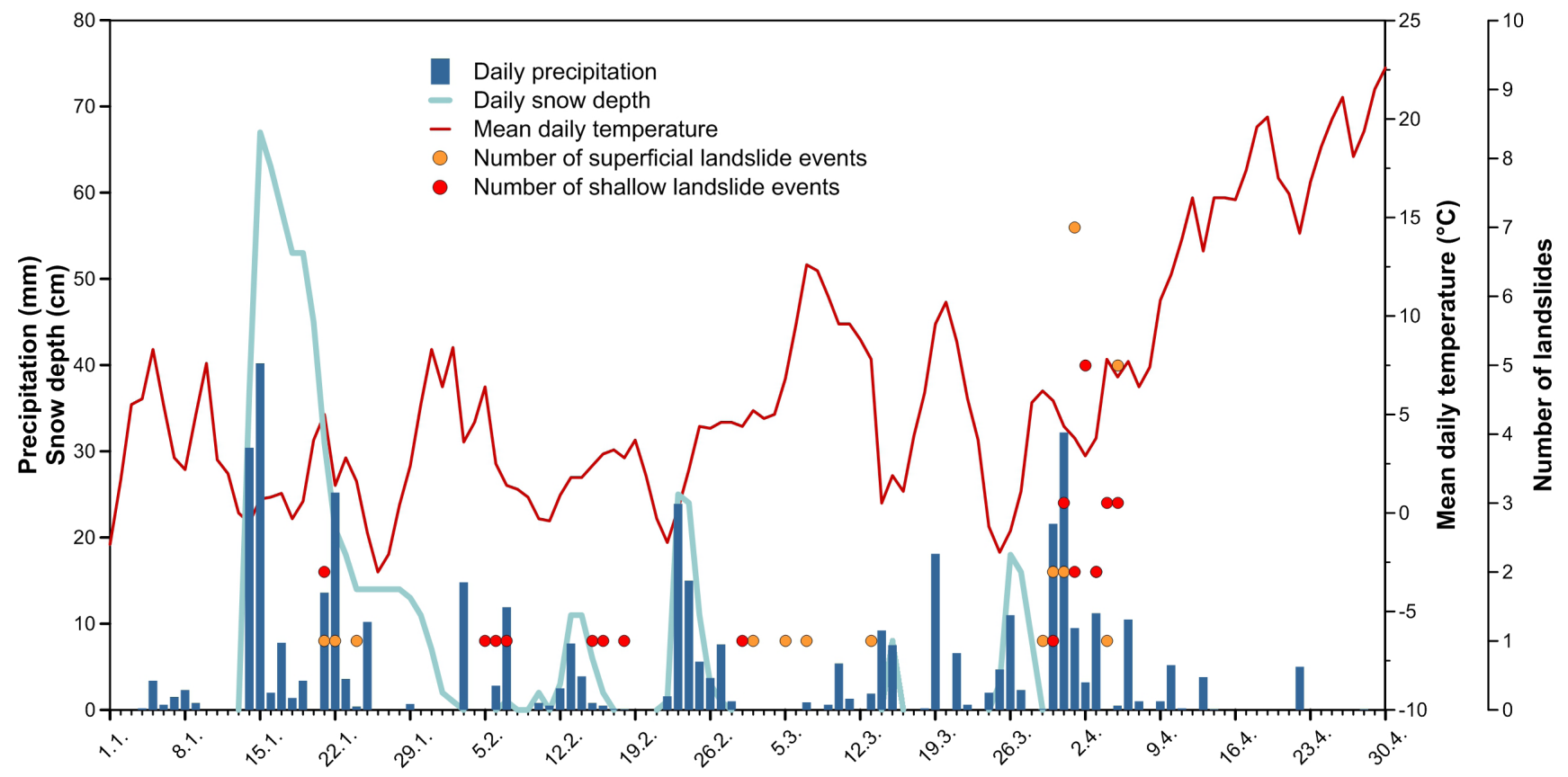

Figure 4. Precipitation data, mean daily temperature and the number of landslide events per date triggered in the City of Zagreb from January to April 2013.

mixtures of unfoliated, mostly impermeable clayey-silty soils that are prone to landslides (NONVEILLER, 1964, 1987; POLAK, 1978). The geological contact between the Miocene sandy-silty soils and the Miocene or Quaternary clayey-silty soils is highly susceptible to sliding (ORTOLAN et al., 2008).
The most frequent aforementioned triggering factors are rainfall (GUZZETTI et al., 2007; JEMEC \& KOMAC, 2013) and man-made activities. Figure 3. presents a precipitation-triggered seasonal landslide inventory with 55 landslides, which were compiled based on information that was collected from the City's ad- 
ministration, online media and field checking by a professional engineering geologist in November 2013 (BERNAT et al., 2014). From 1st January to 7th April 2013, the City of Zagreb experienced a period of intense rainfall and snowfall with cumulative values over the 97-day period that exceeded $400 \mathrm{~mm}$, which represents $46 \%$ of the mean annual precipitation (MAP). The monthly precipitation during the same period in 2013 was two to three times higher than the average monthly values during the same period from 1862 to 2012 that were recorded at the ZagrebGrič meteorological station. An analysis of the 3-month period from January to March showed that the cumulative precipitation for the analyzed period in $2013 \mathrm{had}$ the highest value $(378.7 \mathrm{~mm})$ that was measured over the last 150 years. Figure 4 . depicts the daily precipitation data (amount of rainfall and snow depth) from January to April 2013 and the number of landslide events per day. From the figure it can be seen that landslides occurred after periods of significant rainfall and snow melt. The largest number of landslides (a total of 41 landslide events) occurred during the period from 30th March until 3rd April 2013. According to an analysis of the estimated landslide dimensions, $49 \%$ of all landslides (re)activated in the season from 1st January to 7th April 2013 were superficial landslides (depth $<1 \mathrm{~m}$ ), which occurred in colluvial deposits and/or artificial deposits (fill) that overlaid engineering soil and soft rocks (BERNAT et al., 2014). Moreover, a total of 28 shallow to moderately shallow landslides occurred, with estimated depth ranges of 3-12 $\mathrm{m}$ and maximum landslide areas of $14,000 \mathrm{~m}^{2}$.

\subsection{Historical landslide data}

JURAK et al. (2008) and MIHALIĆ ARBANAS et al. (2012) described all the historical projects that were implemented in the area of the City of Zagreb for landslide mapping, which started in 1967 (MAGDALENIĆ, 1967). Despite the long tradition of landslide mapping in the City, the main problem with the current landslide risk management practices in the City of Zagreb is the lack of a suitable landslide inventory and landslide hazard and risk maps (MIHALIĆ, 1998; MIHALIĆ ARBANAS et al., 2013), which was defined in Van WESTEN et al. (2008) and FELL et al. (2008). An analysis of the spatial distribution of landslides performed by PODOLSZKI (2014) shows that two geomorphological historical inventories from 1967 (ŠIKIĆ, 1967) and 2007 (MIKLIN et al., 2007) contain inconsistent and unreliable landslide data because of an underestimated number of landslides and overestimated landslide areas.

According to a geomorphological historical landslide inventory from 1979 at a scale of 1:10,000 (POLAK et al., 1979), which encompass $105 \mathrm{~km}^{2}$ of the same hilly zone, the total number of mapped landslides is 931, which implies a landslide frequency of $\sim 9$ landslides per square $\mathrm{km}$ (ŠAGUD, 2015). The total landslide area is $2.8 \mathrm{~km}^{2}$ and the resulting landslide density is $2.7 \%$ of the inventory area. The number of landslides is even higher because groups of very small landslides are drawn by single landslide contours, as stated in an accompanying report by POLAK et al. (1979). According to the same historical data, $90 \%$ of the landslides have a landslide area $<10,000 \mathrm{~m}^{2}$ (1 ha).

PODOLSZKI (2014) also performed conventional visual interpretations of stereoscopic aerial photographs from 1964 at a scale of 1:8,000. He also derived a landslide inventory map with an area of $54.14 \mathrm{~km}^{2}$ for 963 landslides, which gives an average landslide density of 17.8 landslides per square $\mathrm{km}$, but reliable identification is estimated for only $50 \%$ of all the mapped landslides. Stereoscopic analysis of historical aerial photographs from
1964 over a large scale enabled the identification of landslides over a range from $78 \mathrm{~m}^{2}$ to $281,886 \mathrm{~m}^{2}$. The landslide areas of most of the landslides (90.6\%) range from $200-3,600 \mathrm{~m}^{2}$.

FERIĆ et al. (2012) performed a preliminary visual analysis of the surface morphology with a 1-m resolution bare-earth airborne LiDAR DEM in 2011 in the test area of the Podsljeme Zone (total area is $24 \mathrm{~km}^{2}$ ). The result of the analysis was an inventory map with 176 landslides and an average landslide density of 7.3 landslides per square $\mathrm{km}$. Most of the mapped landslides are small in size; $60 \%$ of them are smaller than $1,000 \mathrm{~m}^{2}(0.1 \mathrm{ha})$. The smallest identified landslide is an unknown landslide with a landslide area of only $48 \mathrm{~m}^{2}$. The largest identified landslide is a known historical landslide: the Grmošćica landslide, which has a total length of $300 \mathrm{~m}$ and a rupture surface width of $100 \mathrm{~m}$. Approximately $80 \%$ of identified landslides are in the area under forest (BELIĆ et al., 2014).

MIHALIĆ et al. (2012) analyzed data for approximately 82 landslides from site investigation reports that were prepared from 1968 to 2008. Based on available reports, the following information was extracted. The areas of 47 investigated landslides range from 4,000-180,000 $\mathrm{m}^{2}$, and the landslide depths for 15 landslides range from $2-10 \mathrm{~m}$. The data about landslide occurrence time exists only for six landslides in terms of the year when they were activated or reactivated. Reactivated landslides are very common. Landslide causes are known only for 19 landslides ( $23 \%$ of 82 analyzed landslides), and all are of anthropogenic origin from construction activities, mostly the loading of slopes or their crests along the upper part of slopes and water leakage from services (water supplies, sewers, storm-water drains). The same historical data show that the investigation period of some landslides is extremely long. For example, the Bijenik landslide had been investigated a few times between 1968-2004, before it was finally successfully stabilized. Another example of a long investigation period and multiple stabilization works is the Česmički landslide, with a period of geotechnical investigation and design from 1969-2004. JUKIĆ \& SOKOLIĆ (2013) listed approximately 60 landslides that were (re)activated between January to April 2013 and that require stabilization.

An analysis of landslide contours, which are interpreted based on engineering geological field mapping during geotechnical investigations, also shows unreliable landslide contours despite the detailed scale of the topographic base maps that were derived from geodetic surveys (MIHALIĆ ARBANAS et al., 2014). A disadvantage of field mapping is a limited ability to accurately determine a landslide boundary in the field because of the reduced visibility of the slope failure (a consequence of the local perspective), the size of the landslide, and the fact that the landslide boundary is often indistinct or fuzzy (most often because of anthropogenic activities), as stated in SANTANGELO et al. (2010). One example of an unsuccessful design of remedial measures because of the incorrect interpretation of landslide boundaries is the Črešnjevec landslide, which is briefly described in MIHALIĆ et al. (2013). The high uncertainty in the identification of the Črešnjevec landslide's contours in 2001 occurred because of indistinct landslide boundaries, which were interpreted by field mapping approximately 20 years after the landslide occurred and in an environment with significantly modified natural morphology from urbanization between 1982-2001. MIHALIĆ et al. (2013) also showed that the historical landslide boundaries of other landslides in Zagreb vary significantly in size and shape, not only because of the subjectivity of the investigators, but mainly because of the methodology of landslide mapping. 


\subsection{Airborne laser scanning}

Over the last few years, airborne laser scanning has been made available (JABOYEDOFF et al., 2010) and has been used to identify and map landslide morphology in areas that are partially or completely covered by dense vegetation (RAZAK et al., 2011). A relatively new remote-sensing tool uses airborne-mounted lasers to obtain digital representations of the topographic surface for areas that range from a few hectares to thousands of square kilometres (SHAN \& TOTH, 2009). Airborne LiDAR is also known as airborne laser scanning (ALS) or airborne laser swath mapping (ALSM). A laser sensor measures the distance from the instrument and multiple points on the topographic surface. Although laser scanning measures the altitudes of all objects that are scanned, post-processing is necessary to create a bare-earth DEM to remove the undesired returns from buildings and canopies via filtering the original data (REUTEBUCH et al., 2003). The visual analysis and interpretation of the topographic surface remain the most common and most promising applications of a very-highresolution (metric to decimetric) DEM from airborne LiDAR sensors to detect and map landslides over large areas (GUZZETTI et al., 2012). The required resolution of a bare-earth LiDAR DEM to identify landslides primarily depends on the landslide size. Recognizing small cracks and detailed geomorphological features might be one of the most important surface landslide characteristics that can be interpreted from these images, which provides additional information compared to the interpretation of optical images, that is, aerial photos or satellite images.

For the LiDAR data that are used in this study, a test flight (covering $24 \mathrm{~km}^{2}$ ) took place in April 2011 and a flight over the entire study area $\left(180 \mathrm{~km}^{2}\right)$ was undertaken in December 2013, which corresponds to periods after leaf fall in Croatia. The airborne laser scanning system that was used for this research has a measurement rate of $266,000 \mathrm{~Hz}$ at a $60^{\circ}$ angle, with a surface point horizontal accuracy of eight centimetres and vertical accuracy of four centimetres. LiDAR ground-surface measurements were acquired at an average density of five points per square metre. The raw data were post-processed and a 1-m resolution bare earth DEM was interpolated. Slope maps, contour line maps and hillshade maps were created from the DEM by using standard tools in the ArcGIS. A contour line map was created with onemetre intervals, and we chose an altitude angle of $45^{\circ}$ for the light source above the horizon and an azimuth angle of $315^{\circ}$ for the illumination source for the hillshade map. Landslide identification was performed by visual analysis and interpretation of the representation of the topographic surface on all the above-mentioned DEM derivative maps.

\subsection{Results}

The visual identification of the landslides was based on the recognition of landslide features on three topographic derivative maps:

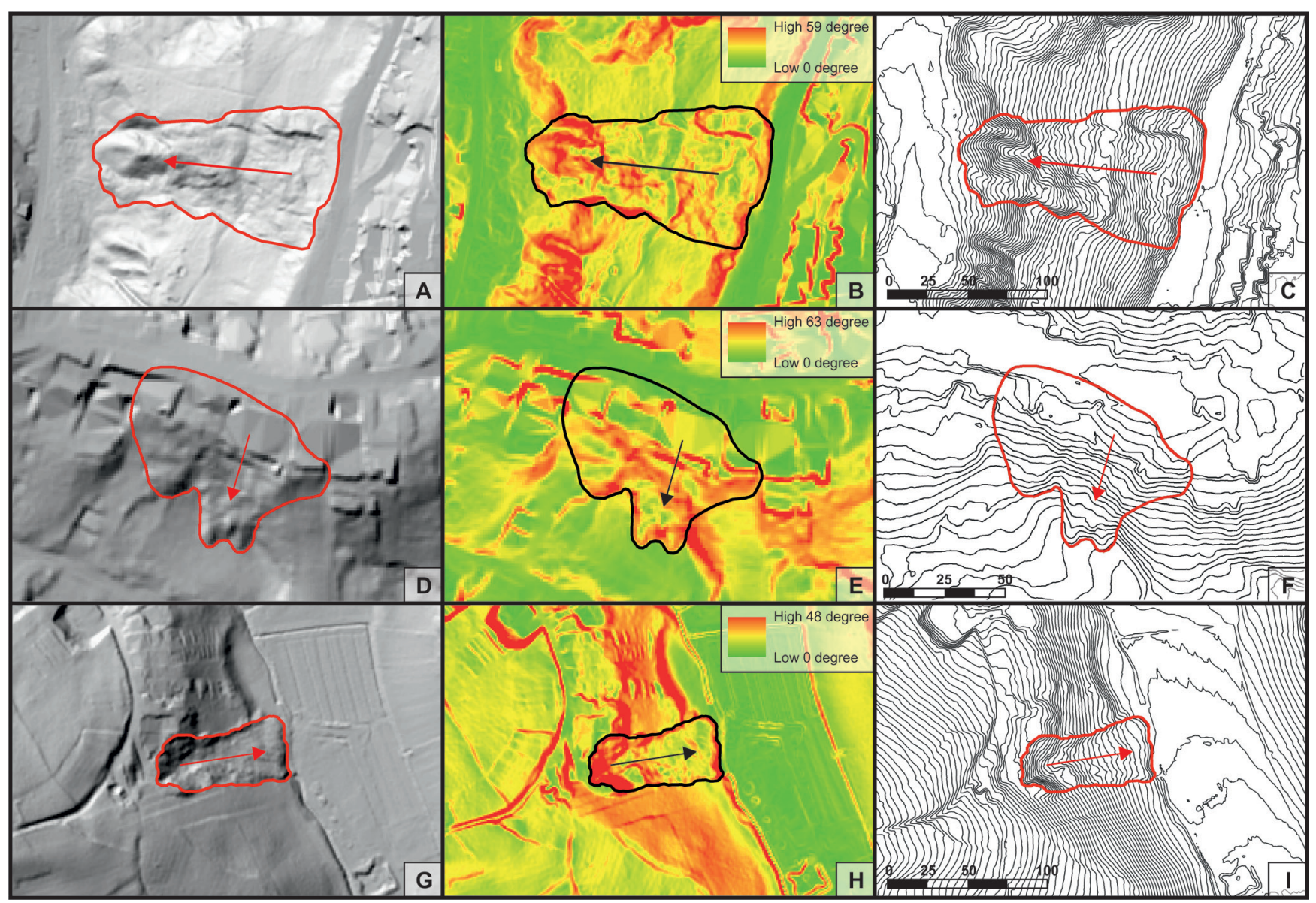

Figure 5. Composite displays of three different topographic derivative maps of the Vrhovec landslide, Črešnjevec landslide and Lazina landslide; the estimated extents of the landslide bodies have red and black contours. (A) Hillshade map of the Vrhovec landslide. (B) Slope map of the Vrhovec landslide. (C) Contour map of the Vrhovec landslide. (D) Hillshade map of the Črešnjevec landslide. (E) Slope map of the Črešnjevec landslide. (F) Contour map of the Črešnjevec landslide. (G) Hillshade map of the Lazina landslide. (H) Slope map of the Lazina landslide. (I) Contour map of the Lazina landslide. The hillshade maps were generated with an azimuth of $315^{\circ}$ and a sun angle of $45^{\circ}$ draped over a bare earth DEM. The slope maps show high slope angles in warmer colours (red, orange, yellow) and low slope angles in cooler colours (green). The contour maps were generated with 1-m contour spacing. 


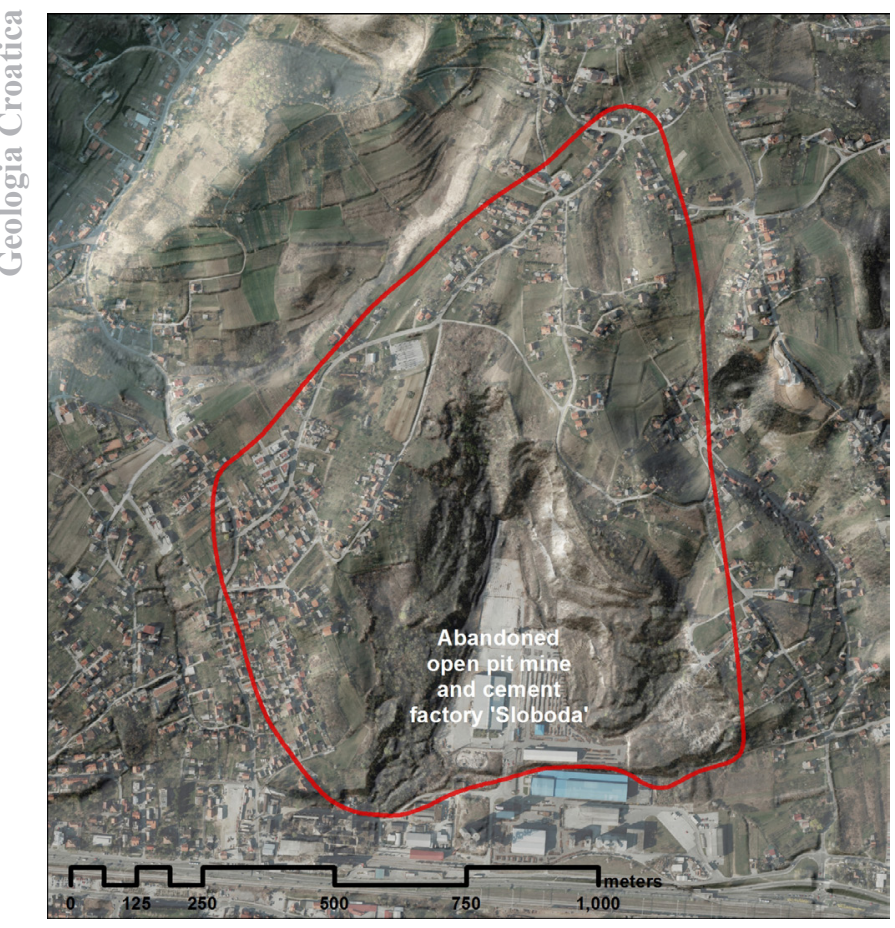

Figure 6. Kostanjek landslide area as depicted by the red line, which represents the landslide contour. In the background is an orthophoto image from March 2012. Devastated slopes of the abandoned open pit mine are expressed by rough relief forms in the middle of the Kostanjek landslide. The former cement factory'Sloboda' was placed in the plain area in the bottom part of the landslide.

a contour map with a one-metre contour span, a hillshade map and a slope map. The mapped landslides were characterized by visible main landslides features such as main scarps, landslide boundaries and toes, zones of depletion and zones of accumulation.

The Vrhovec landslide is readily visible on the hillshade map (Fig. 5A), slope map (Fig. 5B) and contour map (Fig. 5C), although it is an approximately eight-year-old landslide and is currently completely covered by dense vegetation. The steepness of the main scarp is considerably higher than the slope itself. In the slope map, these appear as warmer colours (yellow, orange, red), while the scarp in the contour map is identified by a clustering of elevation contours. Hummocky topography and the flanks and toe of the landslide are also clearly visible. The Vrhovec landslide is a moderately small landslide with an area of $9,923 \mathrm{~m}^{2}$. It is a typical landslide in the investigated area that formed along the geological contact between Pleistocene $\left(\mathrm{Q}_{1}\right)$ fine-grained soils and Pontian $\left(\mathrm{M}_{7}\right)$ sandy-silty soils and was caused by human activities, including uncontrolled disposal in the upper part of the slope.

Figure 5D-F presents the identification results of the previously known Črešnjevec landslide, which is characterized by multiple reactivations of the upper part of the slope after unsuccessful remedial measures in 2004. The red and black lines in Fig. 5D-F depict the contours of an active slow-moving retrogressive landslide. The reactivated landslide is a small, shallow landslide with an area of $3,181 \mathrm{~m}^{2}$. Combining the hillshade, slope and contour maps from the airborne LiDAR data easily distinguishes only the lower part of the displaced mass, while the main scarp, which has a vertical displacement of approximately 10-30 $\mathrm{cm}$, is not clearly expressed. The identification of the landslide contours in the built-up area of the Črešnjevec landslide with airborne LiDAR data was followed by field checking and mapping because of deformations in the bare earth DEM from buildings after post-processing the LiDAR data.
Figure 5G-I shows the clearly visible contour of the Lazina landslide, which was caused by extreme precipitation on $3 \mathrm{rd}$ March 2013. This is also a small and shallow landslide, with an area of $2,842 \mathrm{~m}^{2}$. The Lazina landslide had activated in landfill material, and its vegetation cover was completely removed by landslide events. Figure 2. shows the main scarp of the Lazina landslide photographed after landslide activation in 2013.

\section{LANDSLIDE MONITORING}

\subsection{Kostanjek landslide}

The Kostanjek landslide is a reactivated deep-seated large translational landslide that formed in soft rock-hard soil, i.e., Pannonian and Sarmatian marls. Its landslide velocities have been changing over the last 50 years from landslide activation until the present day, ranging from extremely slow to very slow according to the classification of CRUDEN \& VARNES (1996). Following the initial slow movements that caused settlement and fractures of industrial (cement factory) objects in 1963 and damaging numerous private houses within an area of approximately $1 \mathrm{~km}^{2}$ in a very short period, attention shifted to the unstable slopes above the cement factory, which is known as the Kostanjek landslide (Fig. 6). The initial landslide developed because of a loss in the global stability of gentle to steep slopes above an open pit mine of marls and the cement factory 'Sloboda'. Slope movements were caused by mining activities, i.e., undercutting of the slope toe and uncontrolled massive blasting (STANIĆ \& NONVEILLER, 1996).

According to the photo interpretation of aerial stereo pairs from 1963 to 1988, the horizontal displacements of the ground surface in the period 1963-1988 ranged from 3 to $6 \mathrm{~m}$ (average 12-24 cm per year; ORTOLAN \& PLEŠKO, 1992), as depicted in Fig. 7. The monitoring results of recent movements from 20092012 at 35 stable geodetic points show similar movement directions to historical data (Fig. 7).

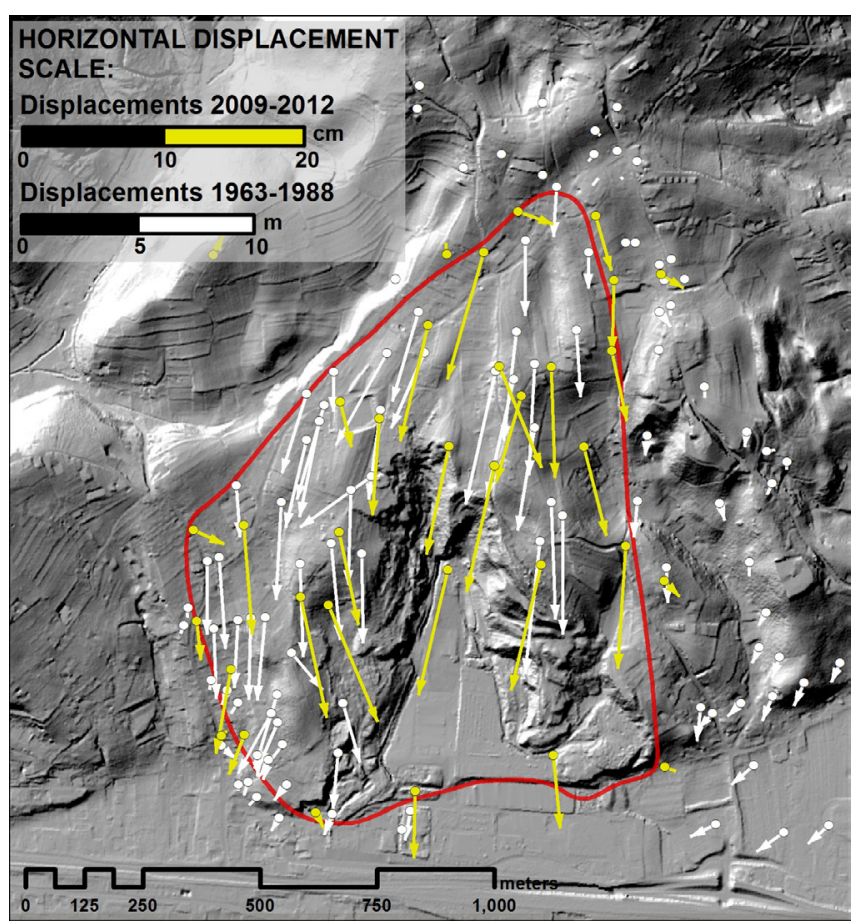

Figure 7. Recent horizontal displacements at the Kostanjek landslide area between 2009-2012 (yellow arrows) compared to historical horizontal displacements (white arrows) for 1963-1988. The red line depicts the Kostanjek landslide contour. 
Although numerous surface exploration and visual studies were undertaken between 1966 and 2010 (briefly described in KRKAČ et al., 2013), the rudimentary nature of the monitoring did not provide conclusive evidence regarding the rate and extent of the movement of the Kostanjek landslide. A geotechnical report prepared by the Croatian Civil Engineering Institute (IGH) in 2008 provided only a comprehensive review of all the historical investigations in the area of the Kostanjek landslide, with a presentation of the historical landslide model and its geometry, mechanism and contributing factors interpreted by ORTOLAN (1996). The subsurface conditions and contours of the landslide bodies that contribute to the movement must be better defined with respect to an interpreted historical movement of the Kostanjek landslide because the specific mechanism of recent movement is not known (KRKAČ et al., 2013).

The main objective of the joint research within the framework of the Japanese-Croatian project was to establish a landslide monitoring system for the purpose of an early warning system (EWS). Landslide monitoring project activities began in 2011. Prior to the completion of the Kostanjek landslide monitoring system, the government of the City of Zagreb determined in January 2011 that the continuous long-term monitoring of the Kostanjek landslide is important for the public safety of the residents. The secondary priority of the monitoring system is to provide an opportunity for the research community to test and develop instrumentation and monitoring technologies and to better understand the mechanics of slow-moving masses.

\subsection{Monitoring system}

The sensor network that was installed in the Kostanjek landslide area encompasses approximately 40 sensors for the monitoring of landslide movement and landslide causal factors. Figure 8. provides the layout of the sensor network that is currently installed at the Kostanjek landslide in the framework of the Kostanjek Landslide Observatory. The monitoring system consists of multiple sensor networks for the measurement of (1) external triggers (a rain gauge, a meteorological station and 7 accelerometers), (2) displacement/deformation/activity (15 GNSS sensors, 7 extensometers, 4 borehole extensometers and an inclinometer), and (3) hydrological properties ( 3 pore pressure gauges and 5 water level sensors in boreholes and domestic wells, and 2 water level sensors at outflow weirs). The general design of the monitoring system is described in KRKAČ et al. (2014b).

Continuous monitoring of external triggers is of crucial importance because of their influence on the reactivation of landslides and the establishment of an EWS. Rainfall, which is one of the most important landslide triggers (MANSOUR et al., 2010), has been monitored with a $0.5 \mathrm{~mm}$ tipping-bucket rain gauge, which is placed in the central part of the Kostanjek landslide, since September 2011. The meteorological station was installed in 2014 because of the limitations of the rain gauge in terms of precipitation measurements during snowy periods (KRKAČ et al., 2014a).

Seven continuously monitoring accelerometers, installed at five locations on the landslide surface and at different depths, record changes according to local ground conditions within the landslide body and in the rock mass below the sliding surface. These accelerometers were installed to record ground shaking (accelerations) in response to earthquakes (trigger) and in response to landslide movements (activity).

Slope movement monitoring provides data about the actual state of landslide activity through observations of slope movement parameters (displacement, velocity and acceleration) on the surface of a landslide. This process enables the recognition and quantification of reactivation phases and definition of threshold values approaching critical acceleration and, ideally, enables the forecasting of the catastrophic sliding phases (BAROŇ et al., 2012). High-resolution temporal and spatial data at the Kostanjek landslide were obtained from surface movement monitoring by the GNSS (Global Navigation Satellite System) sensor network (system of satellites and Earth stations for precise positioning on Earth's surface) and a large number of wire extensometers (sensors that measure the relative displacement between two points). Fifteen densely distributed GNSS sensors (double-frequency NetR9 TI-2 GNSS reference station with Zephyr Geodetic 2 GNSS antenna, Trimble) provide highly accurate data, which depends on the post-processing time. For example, the temporal resolution of the data can be every second in the real-time kinematic mode. These near-real-time and real-time movement data satisfy the requirements for failure prediction by using, for example, FUKUZONO's (1985) method. Seven wire extensometers (NetLG-501E, Osasi Technos Inc.) provide data every hour. Unreliability in the extensometer data can be caused by the influence of meteorological conditions, which must be considered during interpretation of the landslide movement parameters.

Subsurface movement at the Kostanjek landslide, which was measured by inclinometer, provided reliable data regarding the sliding surface depth, mechanical behaviour and displacement from April 2012 to February 2013. After this period, the inclinometer casing became impassable because of a large displacement along the sliding surface. Although the inclinometer data are of good quality, both the temporal (a few measurements in one year) and spatial resolution (only one borehole with inclinometer casing in the central part of the landslide) are very poor. Higher spatial resolution is necessary to confirm the existing prognostic landslide model. Monitoring the subsurface movement at the central location of the landslide was improved by installing four vertical wire extensometers at different depths in the borehole near the existing inclinometer casing. These devices will provide continuous displacement monitoring data even for larger displacements.

The hydrological conditions have the most significant influence on landslide behaviour, e.g., changes in the pore water pressure and groundwater levels. Continuous observations of pore water pressure and groundwater level at the Kostanjek landslide provide good temporal data (every hour). The sensors were installed at a few locations in different parts of the landslide body, as depicted in Fig. 8. Three piezometers with pore pressure gauges were installed in the central part of the landslide body, one is in the zone of the sliding surface and two are in the landslide mass. Two water level gauges were installed in the central part of the landslide, while three water level gauges were installed on the western, northwestern and northern landslide boundaries. Although the water level sensors that were installed near the landslide boundary do not actually measure the water level in the sliding surface area, the data show good correlation with landslide movements.

\subsection{Monitoring results}

Landslide movement sensors recorded multiple reactivations of the Kostanjek landslide from external triggers in 2013 and 2014. KRKAČ (2015) identified five periods of faster movement (landslide reactivations) based on analyses of observations from the GNSS network. The cumulative horizontal displacements that were recorded by the GNSS sensor network over these two years are shown in Fig. 8. The maximal displacement of $426 \mathrm{~mm}$ was 


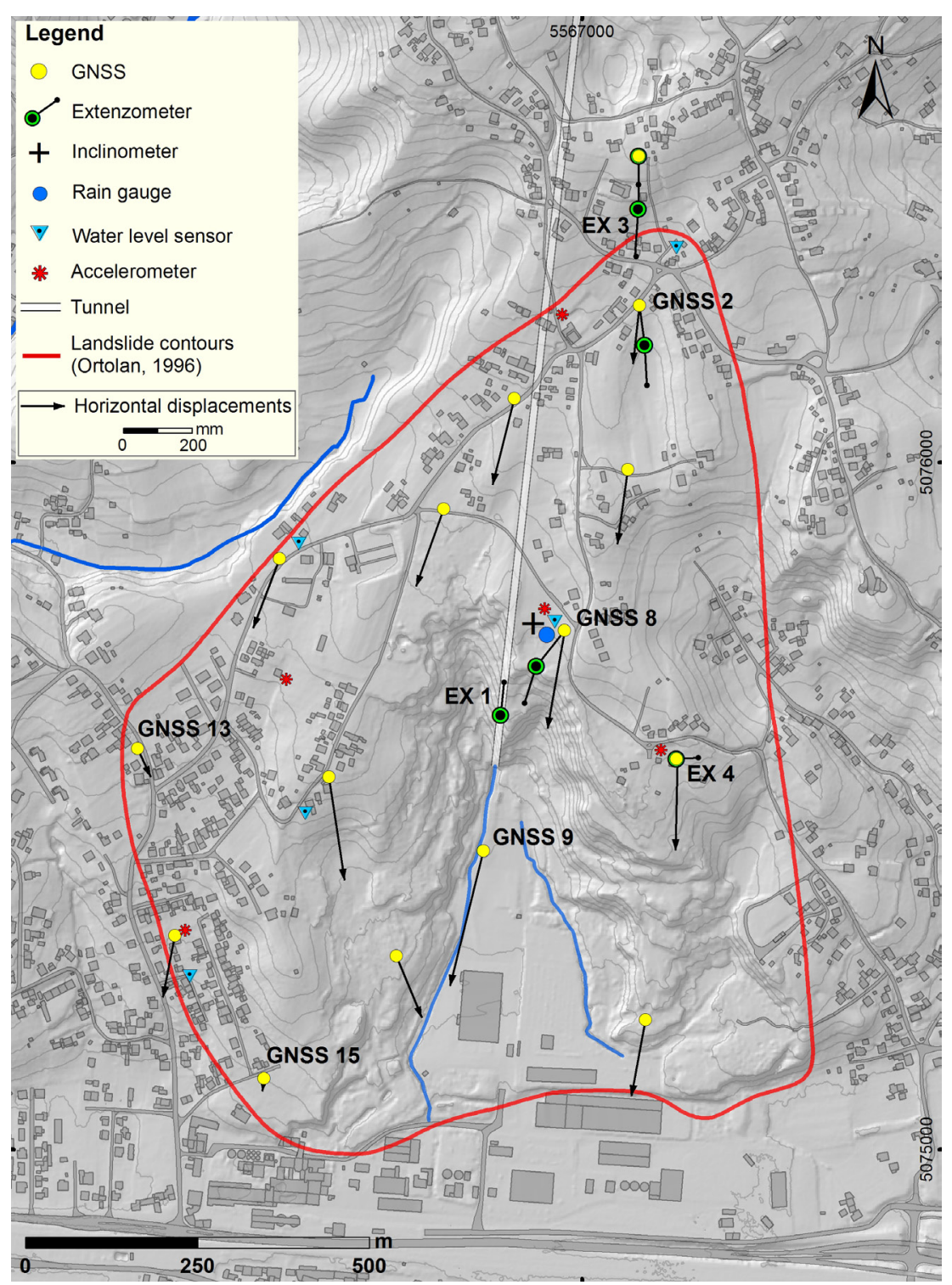

Figure 8. Locations of the monitoring sensors at the Kostanjek landslide and the cumulative horizontal displacements that were recorded by the GNSS sensor network from January 2013 to January 2015 (according to KRKAČ, 2015). The red line depicts the Kostanjek landslide contour.

measured in the lower central part of the landslide (GNSS 9), while the minimal displacement of $38 \mathrm{~mm}$ (GNSS 15) was measured along the southwestern landslide boundary. The amount of displacement in the central part of the landslide and in the foot part is approximately two to four times higher than the displacement near the landslide's boundaries (Fig. 8).
Figure 9. shows the evolution of the 2D surface displacement that was registered by four GNSS sensors. During the monitoring period, the first and most intensive period of faster movement occurred from 22nd January to 24th May 2013 (Fig. 9). During this period, the horizontal displacements ranged from $36.9 \mathrm{~mm}$ at the northwestern landslide boundary (GNSS 13) to $168 \mathrm{~mm}$ in

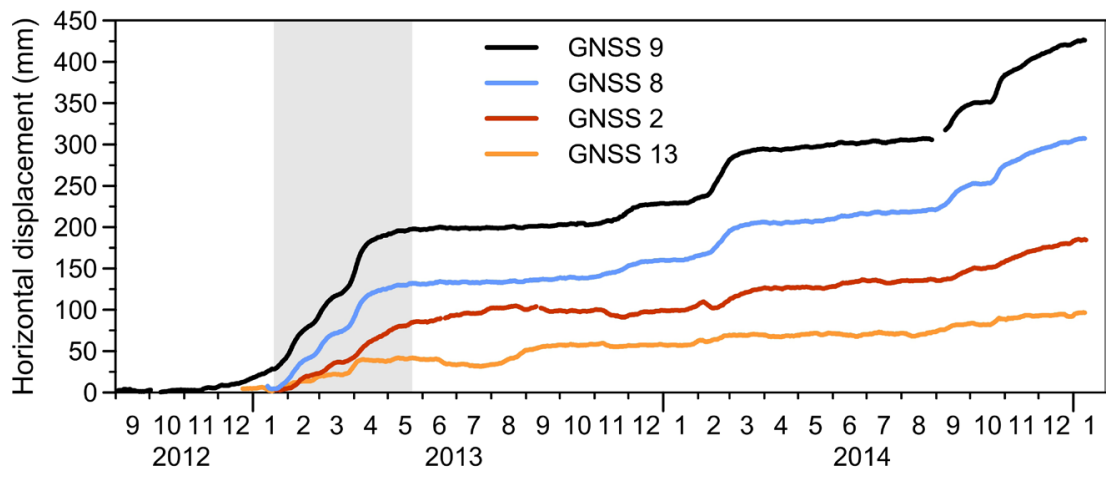

Figure 9. Cumulative horizontal displacements versus time for GNSS 2 and 13 (near the landslide boundary), GNSS 8 and GNSS 9 (in the central part of the landslide). The gray area indicates the first period of faster movement. 


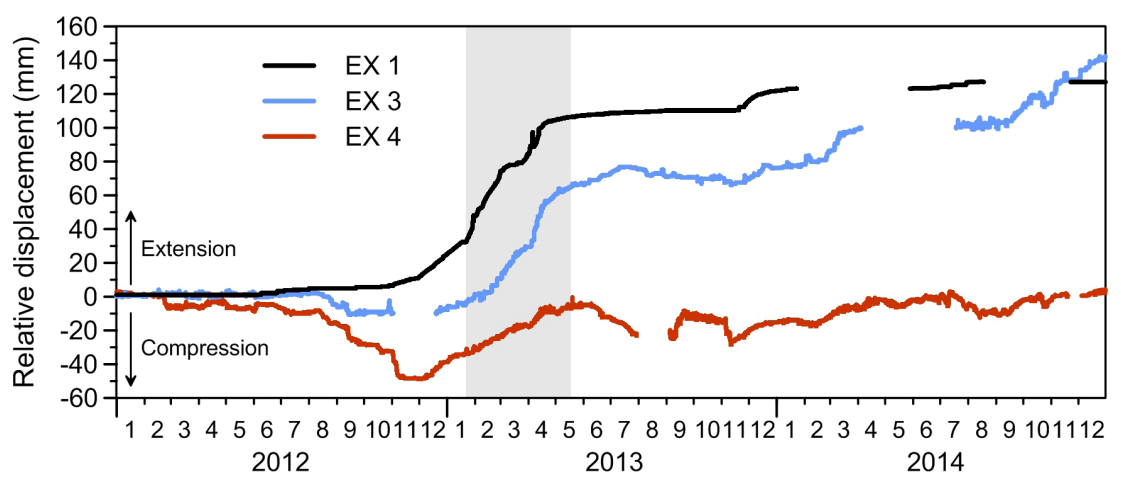

Figure 10. Relative displacements versus time for EX 1 (extensometer below ground installed across the sliding surface in the abandoned tunnel), EX 3 (extensometer at the surface installed across the main scarp) and EX 4 (extensometer at the surface installed across a fracture in the eastern part of the Kostanjek landslide). The gray area indicates the first period of faster movement.
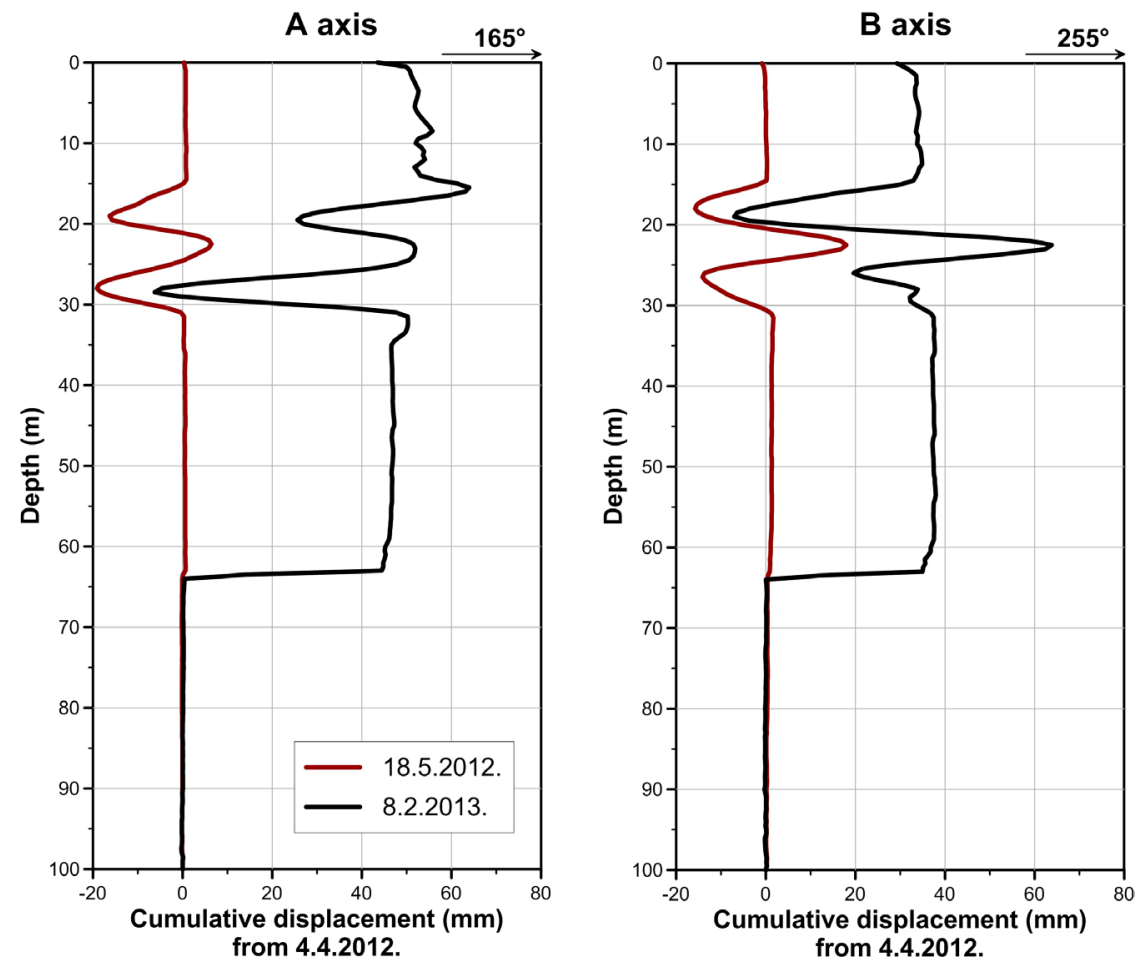

Figure 11. Cumulative inclinometer displacements for the A and B axes (according to KRKAČ et al., 2014a).

the lower central part of the landslide (GNSS 9). The maximum recorded velocities were from $1.8 \mathrm{~mm} /$ day (GNSS 2, located at the northern boundary) to $4.8 \mathrm{~mm} /$ day (GNSS 9). The maximum rates of displacement, with velocities of 2 to $4.8 \mathrm{~mm} / \mathrm{day}$, occurred during the first week of April. The first period of faster movement was caused by a total precipitation amount of 455.2 mm from December 2012 to March 2013.

During the monitoring period, three of the seven installed extensometers showed significant displacement, namely, the long-span extensometer (EX 3) that crosses the main scarp, the short-span extensometer (EX 4) that crosses the fracture in the eastern part of the landslide and the short-span extensometer (EX 1) that crosses the sliding surface in the abandoned tunnel (Figs. $8 \& 10$ ). The maximum recorded relative displacement was $142 \mathrm{~mm}$, which was measured by the extensometer that crosses the main scarp (EX 3). During the first period of faster movement, all three extensometers displayed extension, but the amount of measured relative displacement varied from $40 \mathrm{~mm}$ along the fracture on the eastern side of the landslide body to $72.5 \mathrm{~mm}$ on the main scarp and $97 \mathrm{~mm}$ in the central part, where the sliding surface intersects the tunnel (Fig. 10).

An inclinometer tube was installed in March 2012 in a $100 \mathrm{~m}$-deep borehole in the central part of the landslide. The inclinometric profile, which was obtained based on three measurements, indicates that the failure occurred in a thin basal shear zone at a depth of $62.5 \mathrm{~m}$ (Fig. 11). Deformation above $62.5 \mathrm{~m}$ can be considered negligible in terms of landslide mechanisms. Deformation at depths of 15 to $30 \mathrm{~m}$ is probably a consequence of borehole casing deformation from improper inclinometer tube installation and voids between the inclinometer casing and the in-situ ground (KRKAČ et al., 2014a).

\subsection{Preliminary application of monitoring results}

GRADIŠKI et al. (2013) presented slope stability analyses of the Kostanjek landslide (Fig. 12) with the LS-RAPID software (Integrated Landslide Simulation Model) (SASSA \& HE, 2013). An existing landslide model from ORTOLAN (1996) was modified based on the monitoring results by creating an ellipsoidal sliding 


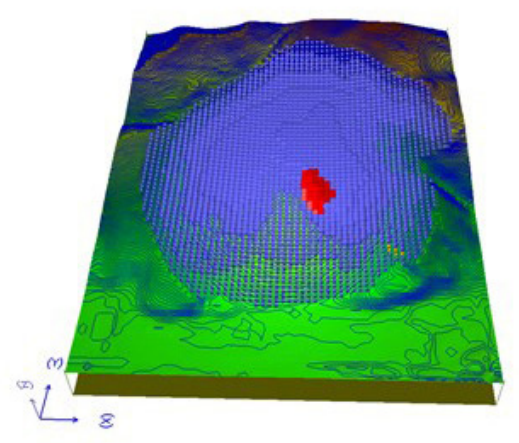

$r_{u}=0.3$

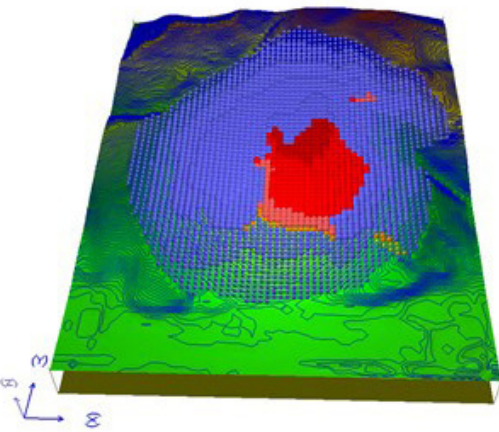

$r_{\mathrm{u}}=0.5$

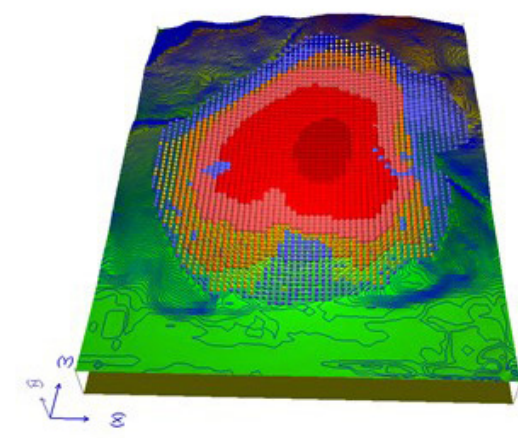

$r_{u}=0.8$

Figure 12. Slope stability analyses of the Kostanjek landslide for $r_{u}=0.3, r_{u}=0.5$, and $r_{u}=0.8$ (according to GRADIŠKI et al., 2013).

surface with a maximum depth of $65 \mathrm{~m}$ in the central part of the landslide body (according to the maximum displacements). The parameters that were used for these analyses were determined from drained test samples in a ring shear apparatus, which was performed in the framework of the Japanese-Croatian project. Analyses were performed for the assumed pore pressure on the sliding surface. According to the results of the analyses, the most unstable part of the landslide is the central part of the landslide body, the slopes of the abandoned open marl pit. In the analyses, the movements started in the central part of the landslide body, and the failure area expanded around the initial failure zone. At the end of the simulation, the area of the entire landslide mass corresponded to the landslide contour from the historical landslide model according to ORTOLAN (1996). This is also in accordance with the new surface deformations (cracks, bulging, and subsidence) that developed during very recent landslide movement in 2013-2014, as shown by the arrows in Fig. 8 .

More reliable analyses require defining the following factors more precisely: the sliding surface, with more correct positions along particular landslide cross sections; the groundwater table surface, which needs to be derived based on measured groundwater levels; and soil parameters, determined from additional undrained ring shear tests. Additional subsurface investigations, necessary to interpret more reliably the sliding surface depths, include drilling of boreholes with depths of 10-95 m, followed by soil/rock determination and inclinometer monitoring. The groundwater table surface must be monitored and measured continuously by at least seven piezometers.

\section{DISCUSSION}

This paper describes two groups of methodologies that were applied in the framework of the scientific Japanese-Croatian SATREPS FY2008 project (2009-2014) in the hilly area of Medvednica Mt. in the City of Zagreb. Both the methodology for landslide identification and mapping and the methodology for landslide monitoring are based on new advanced technologies, which enable the development of appropriate methods for the specific engineering geological conditions in the study area of the Podsljeme Zone. The general objective of the research was to discover methods to efficiently gather more reliable data regarding existing landslides in both detailed and large scales to satisfy the requirements of land use planning, construction and civil protection within the City. This discussion presents the main advantages and disadvantages of the tested methodologies.

Within the framework of the study that was described in the paper, we verified a visual analysis of airborne LiDAR DEMs with 1-m resolution for landslide identification and mapping. Data captured at the end of 2013 enabled visual mapping of all the landslides that (re)activated during the extremely wet season in 2013, along with old landslides, with sizes greater than $50 \mathrm{~m}^{2}$. No limitation exists in terms of the maximum landslide area. The Vrhovec and Lazina landslides illustrate the main advantages of landslide identification from very-high-resolution bare-earth DEMs: (i) readily visible landslide features (main scarp, landslide flanks and toes, the morphologies of depletion and accumulation zones) of the 8-year-old landslide that are completely covered by dense vegetation (scrub and forest) and new landslides that are partially covered by vegetation; and (ii) the ability to accurately determine a landslide boundary from completely visible slope failures (a consequence of the aerial perspective) and to determine the size of a landslide. The Črešnjevec landslide illustrates the main disadvantage of landslide identification from very-high-resolution bare-earth DEMs. Built-up zones prevent the identification of landslide features because of deformation that remains in the bare-earth DEM after post-processing. Consequently, the landslide boundary is often indistinct or fuzzy, as in the upper part of the Črešnjevec landslides, where the main scarp and landslide flanks around the depletion zone in the landslide body were identified exclusively with field checking. In the Podsljeme Zone, the limitations of visual interpretations of DEM-derivative maps in built-up areas can easily be overcome by field checking because only approximately $20 \%$ of the area is urbanized. These areas are easy to approach because of a dense network of roads, which will enable map validation and the verification of specific problematic areas. Moreover, field checking areas of less than $15 \%$ is usual during landslide inventory mapping (GALLI et al., 2008).

The Kostanjek landslide presents a risk for approximately 290 buildings (mostly residential houses) in an area of one square kilometre in the urban part of the City of Zagreb. The automated continuous monitoring sensor network provided good quality data for the establishment of relationships between landslide movement parameters and the triggering causal factor parameters to predict faster movements, accelerated movement and/or large displacements. The monitoring sensors at the Kostanjek landslide recorded multiple landslide reactivations from external triggers, such as during the winter of 2012/2013 and the spring of 2013. The advantages of the monitoring system at the Kostanjek Landslide Observatory are as follows: (i) using multiple sensors for the purpose of movement monitoring at the same position in the central part of the landslide (consisting of a GNSS station, extensometer, inclinometer and vertical extensometer), guarantees redundant measurements and can prevent data loss if one instrument fails; 
(ii) using the same position for different types of movement monitoring sensors in the central part of a landslide (consisting of the aforementioned sensors) also enables the spatial correlation of measurement data on the landslide surface and within the landslide profile; and (iii) using different geodetic and geotechnical sensors in combination with hydrological monitoring equipment (measuring precipitation and pore pressures in the landslide profile) allows a reconstruction of the relationships between rainfall, groundwater level, and consequent landslide behaviour as a basis for establishing an early warning system. However, the main disadvantages of the Kostanjek monitoring system are related to missing sensors in all parts of this large and deep-seated landslide. Additional inclinometers in different parts of the landslide are necessary to provide reliable data regarding the geometry of the entire sliding surface. Additional piezometers are also necessary in different parts of the landslide to provide measurements of pore water pressure to better understand the landslide behaviour and correlation with causal factors. The greater displacements in the central part of the landslide compared to the displacement along the landslide boundaries implies the necessity of identifying zones within the landslide body with different hazard and risk levels. This can be achieved by combining the described series of monitoring data from the Kostanjek landslide with other advanced remote sensing technologies. TOFANI et al. (2013) and KOMAC et al. (2015) integrated Persistent Scatterer Interferometry (PSI) data with in situ monitoring instrumentation and showed that the joint use of satellite and ground-based data with the geological interpretation of a landslide allows a better understanding of landslide geometry and kinematics. The integration of ground-based monitoring data and PSI data are potentially providing sound results for the characterization of the slow-moving Kostanjek landslide.

Defining the state of activity of numerous very small to moderately large landslides (primarily $<10,000 \mathrm{~m}^{2}$ ), along with the large Kostanjek landslide, would be useful when dealing with landslide identification, mapping, monitoring and hazard analysis in the City of Zagreb. In particular, satellite SAR (Synthetic Aperture Radar) interferometry (TOFANI et al., 2013) has proven to be a sound tool to assess changes on the Earth's surface for landslide mapping and monitoring purposes. PSI represents a powerful tool to measure landslide displacement because it offers a synoptic view that can be repeated at different time intervals and at various scales.

\section{CONCLUSIONS}

This study described landslides in the hilly area of the Medvednica Mt. in the City of Zagreb as the main geological hazard, as proven in 2013 by the activation of new or reactivation of old landslides when approximately 60 slope movements endangered residential houses and roads, including the large, deep-seated 50 -year-old Kostanjek landslide. The overview of existing information and knowledge regarding landslides in the City of Zagreb proves the need for the application of new advanced technologies, which will enable the fast and efficient gathering of data regarding landslide locations, exact landslide contours, the state of activity and the time of (re)activation.

The landslide inventory map of the large hilly area in the City of Zagreb $\left(180 \mathrm{~km}^{2}\right)$ can be derived from the visual interpretation of a very-high-resolution bare-earth DEM that was captured by airborne LiDAR sensors. The 1-m resolution enables the identification of detailed geomorphological features and the precise interpretation of contours of very small to moderately small landslides $\left(<10,000 \mathrm{~km}^{2}\right)$, which are typical for the study area. By providing insight into landslides in highly vegetated areas, which are most often in the studied Podsljeme Zone ( $70 \%$ covered by forest), this advanced method is proposed as the most appropriate for landslide identification compared to the interpretation of optical images, that is, aerial photos or satellite images.

Prospective uses of the visual interpretation of very-highresolution bare-earth DEMs from airborne LiDAR sensors in the Podsljeme Zone include landslide inventory mapping to produce reliable inventories of all landslide phenomena that are or have been active in an area, independent of its size or time of activation. Reliable landslide inventory maps will enable further analysis of existing landslides (in the form of landslide distribution maps), or the prognosis of landslide hazards (in the form of landslide susceptibility and hazard maps), which are necessary for the strategic planning of landslide management within the entire Podsljeme Zone. Derived information regarding landslides will be used by the City administration to work with land use planning, construction and civil protection.

In addition to the precise identification of landslide contours, the most dangerous landslides, which present high societal risks, should be continuously monitored by sensors for their movements and triggers (precipitation, groundwater level, earthquakes). Analysis of continuous series of data from observations of the Kostanjek landslide showed five periods of reactivation in 2013 and 2014 that were characterized by movement parameters (displacement, distance, velocity and acceleration) that enable the temporal and spatial interpretation of landslide reactivations. Temporal information regarding faster sliding enabled correlations with triggering factors, i.e., the determination of particular periods of groundwater changes and periods of higher precipitation and the interpretation of the hydrological conditions that led to sliding. Spatial information regarding the distribution of slope movement along displaced masses (on the surface and in the underground) of the Kostanjek landslide enabled more reliable modeling of future landslide movements in the entire landslide area.

The perspective on the future analysis of continuous observations of the Kostanjek landslide and its application to the prognosis of landslide hazard and risk includes the development of an early warning system in the area of the Kostanjek landslide. Reliable data series that were gathered by the monitoring sensor networks of the Kostanjek Landslide Observatory include source data for modeling the relationships between landslide movement parameters and landslide causal factor parameters. Empirical models will define the threshold values of landslide movement parameters and the triggers of sliding, which are necessary for the prognosis of possible movements within the Kostanjek landslide, i.e., the evaluation of landslide hazard. Moreover, the same models will provide source data for the simulation of different scenarios through numerical modeling of landslide movements and the production of landslide hazard and risk maps for the Kostanjek landslide.

\section{Acknowledgment}

The results presented herein have been obtained with financial support from JST/JICA's SATREP FY2008 Program (Science and Technology Research Partnership for Sustainable Development). Co-financing was ensured from the Ministry of Science, Education and Sports of the Republic of Croatia, the City Office for Physical Planning, Construction of the City, Utility Services and Transport, City of Zagreb and the Emergency Management Office of the City of Zagreb. These supports are gratefully acknowledged. The authors would like to express our great appreciation to the company Trimble and Geomatika-Smolčak Ltd. for spon- 
soring the Kostanjek Landslide Observatory and to the City Office for the Strategic Planning and Development of the City, City of Zagreb and the Meteorological and Hydrological Service of the Republic of Croatia (DHMZ) for allowing us to use digital data from their archives. The authors are grateful to anonymous reviewers for their invaluable advices.

\section{REFERENCES}

ARBANAS, Ž., SASSA, K., MARUI, H. \& MIHALIĆ, S. (2012): Comprehensive monitoring system on the Grohovo Landslide, Croatia.- In: EBERHARDT, E., FROESE, C., TURNER, K. \& LEROUEIL, S. (eds.): Landslides and Engineered Slopes: Protecting Society through Improved Understanding, Proceedings of the 11th International \& 2nd North American Symposium on Landslides, Banff, Canada, June 3-8, 2012. Taylor and Francis Group, London, 1441-1447.

ARDIZZONE, F., CARDINALI, M., GALLI, M., GUZZETTI, F. \& REICHENBACH, P. (2007): Identification and mapping of recent rainfall-induced landslides using elevation data collected by airborne LiDAR.- Natural Hazards and Earth System Sciences, 7/6, 637-650.

AVANIĆ, R., KOVAČIĆ, M., PAVELIĆ, D., MIKNIĆ, M., VRSALJKO, D., BAKRAČ, K. \& GALOVIĆ, I. (2003): The middle and upper Miocene facies of Mt. Medvednica (Northern Croatia).- In: VLAHOVIĆ, I \& TIŠLJAR, J. (eds.).: Evolution of Depositional Environments from the Palaeozoic to the Quaternary in the Karst Dinarides and the Pannonian Basin, 22nd IAS Meeting of Sedimentology, Opatija, Croatia, Sept. 17-19, 2003. Institute of Geology, Zagreb, 167-172.

BAROŇ, I., SUPPER, R. \& OTTOWITZ, D. (2012): Report on evaluation of mass movement indicators, SafeLand deliverable D4.6.- Geological Survey of Austria, Vienna, $382 \mathrm{p}$.

BELIĆ, N., MIHALIĆ ARBANAS, S., ŠIŠKO, D. \& GAJSKI, D. (2014): Derivation of historical land cover map based on digital orthophoto images of the Zagreb Area.In: MIHALIĆ ARBANAS, S. \& ARBANAS, Ž. (eds.): Landslide and Flood Hazard Assessment, Proceedings of the 1st Regional Symposium on Landslides in theAdriatic-Balkan Region, Zagreb, Croatia, March 6-9, 2013. Croatian Landslide Group, Zagreb, 63-66.

BERNAT, S., MIHALIĆ ARBANAS, S. \& KRKAČ, M. (2014): Inventory of precipitation triggered landslides in the winter of 2013 in Zagreb (Croatia, Europe).- In: SASSA, K., CANUTI, P. \& YIN, Y. (eds.): Proceedings of the 3rd World Landslide Forum, Landslide Science for a Safer Geoenvironment, Volume 2: Methods of Landslide Studies, Beijing, China, June 2-6, 2014. Springer, Cham, 829-836.

BERNAT, S., MIHALIĆ ARBANAS, S. \& KRKAČ, M. (2015): Catalog of precipitation events that triggered landslides in northwestern Croatia.- In: Proceedings of the 2nd Regional Symposium on Landslides in the Adriatic-Balkan Region, Beograd, Serbia, March 6-9, 2013. In press.

BLIKRA, L.S. (2012): The Åknes rockslide, Norway.- In: CLAGUE, J.J., STEAD, D. (eds.): Landslides - Types, Mechanisms and Modeling. Cambridge University Press, Cambridge, 323-334.

BRÜCKL, E., BRUNNER, F.K. \& KRAUS, K. (2006): Kinematics of a deep-seated landslide derived from photogrammetric, GPS and geophysical data.- Engineering Geology, 88, 149-159.

CASTAGNETTI, C., BERTACCHINI, E., CORSINI, A. \& CAPRA, A. (2013): Multisensors integrated system for landslide monitoring: Critical issues in system setup and data management.- European Journal of Remote Sensing, 46, 104-124.

CESAREC, M. \& POLAK, K. (1986): Klizišta na području grada Zagreba [Landslides in the area of the Zagreb City - in Croatian].- In: Proceedings of the XVI Symp. YSSMFE, Aranđelovac, Yugoslavia, Nov. 5-8, 1986. 169-184.

CORSINI, A., PASUTO, A., SOLDATI M. \& ZANNONI, A. (2005): Field monitoring of the Corvara landslide (Dolomites, Italy) and its relevance for hazard assessment.- Geomorphology, 66, 149-165.

COTECCHIA, V. (2006): The Second Hans Cloos Lecture. Experience drawn from the great Ancona landslide of 1982.- Bulletin of Engineering Geology and the Environment, $65,1-41$.

CRUDEN, D.M. \& VARNES, D.J. (1996): Landslide types and processes.- In: TURNER, A.K. \& SCHUSTER, R.L. (eds.): Landslides: Investigation and Mitigation, Transportation. Research Board Special Report 247, National Research Council, Washington, D.C., 36-75.

ĐOMLIJA, P., BERNAT, S., MIHALIĆ ARBANAS, S., \& BENAC, Č. (2014): Landslide inventory in the area of Dubračina River Basin (Croatia).- In: SASSA, K., CANUTI, P. \& YIN, Y. (eds.): Proceedings of the 3rd World Landslide Forum, Landslide Science for a Safer Geoenvironment, Volume 2: Methods of Landslide Studies, Beijing, China, June 2-6, 2014. Springer, Cham, 837-842.

FELL, R., COROMINAS, J., BONNARD, C., CASCINI, L., LEROI, E. \& SAVAGE W.Z. (2008): Guidelines for landslide susceptibility, hazard and risk zoning for land use planning.- Engineering Geology, 102, 85-98.

FERIĆ, P., MIHALIĆ, S. \& KRKAČ, M. (2012): Visual mapping of landslides from LiDAR imagery, Zagreb, Croatia.- In: OŽANIĆ, N., ARBANAS, Ž., MIHALIĆ, S., MARUI, H. \& DRAGIČEVIĆ, N. (eds.): Proceedings of the 2nd Workshop of the Croatian-Japanese SATREPS FY2008 Project, Rijeka, Croatia, Dec. 15-17, 2011. University of Rijeka, Rijeka, 130-133.

FIJEMBER, M. (1942): Klizanje tla zagrebačkih obronaka [Landslides in the hilly area of the City of Zagreb - in Croatian].- Tehnički vjesnik, 59, 20-29.

FROESE, C.R., CHARRIÈRE, M., HUMAIR, F., JABOYEDOFF, M. \& PEDRAZZINI, A. (2012): Characterization and management of rockslide hazard at Turtle Mountain, Alberta, Canada.- In: CLAGUE, J.J. \& STEAD, D. (eds.): Landslides Types, Mechanisms and Modeling. Cambridge University Press, Cambridge, 310-322.

FUKUZONO, T. (1985): A new method for predicting the failure time of a slope.- In: Proceedings of 4th International Conference and Field Workshop on Landslides. Japan Landslide Society, Tokyo, 145-150.

GALL, M., ARDIZZONE, F., CARDINALI, M., GUZZETTI, F. \& REICHENBACH, P. (2008): Comparing landslide inventory maps.- Geomorphology, 94, 268-289.

GRADIŠKI, K., KRKAČ, M., MIHALIĆ ARBANAS, S. \& BERNAT, S. (2013): Slope stability analyses of the Kostanjek Landslide for extreme rainfalls in the winter of 2013.- In: VLASTELICA, G., ANDRIĆ, I. \& SALVEZANI, D. (eds.): Book of abstracts, 4th workshop of the Japanese-Croatian project on Risk Identification and Land-Use Planning for Disaster Mitigation of Landslides and Floods in Croatia, Split, Croatia, Dec. 12-14, 2010. University of Split, Faculty of Civil Engineering, Architecture and Geodesy, 15-16.

GUZZETTI, F., MONDINI, A.C., CARDINALI, M., FIORUCCI, F., SANTANGELO, M. \& CHANG. K.T. (2012): Landslide inventory maps: New tools for an old problem.- Earth-Science Reviews, 112, 42-66.

GUZZETTI, F., PERUCCACCI, S., ROSSI, M. \& STARK, C. P. (2007): Rainfall thresholds for the initiation of landslides in central and southern Europe.- Meteorology and Atmospheric Physics, 98, 239-267.

JABOYEDOFF, M., OPPIKOFER, T., ABELLAN, A., DERRON, M.H., LOYE, A., METZGER, R. \& PEDRAZZINI, A. (2010): Use of LIDAR in landslide investigations: A review.- Natural Hazards, 61/1, 5-28.

JEMEC, M. \& KOMAC, M. (2013): Rainfall patterns for shallow landsliding in perialpine Slovenia.- Natural Hazards, 67/3, 1011-1023.

JUKIĆ, M. \& SOKOLIĆ, Ž. (2013): Tehničko promatranje sustava za prihvat i odvodnju voda kao jedan od osnovnih elemenata u strategiji zaštite od klizišta [Technical survey of water recharge and drainage as one of the basic element in strategy of slope remediation - in Croatian].- In: MATEŠIĆ, L. \& SOKOLIĆ, I. (eds.): 6. Savjetovanje Hrvatskog geotehničkog društva, Sanacija, tehničko praćenje i održavanje u geotehnci, Zadar, Peruća, Croatia, Oct. 17-19, 2013. Hrvatsko geotehničko društvo, 173-179.

JURAK, V., MATKOVIĆ, I., MIKLIN, Ž. \& MIHALIĆ, S. (1996): Data analysis of the landslides in the Republic of Croatia: Present state and perspectives.- In: SENNESET, K. (ed.): Proceedings of the 7th International Symposium on Landslides, Trondheim, Norway, June 17-21, 1996. CRC Press, Taylor \& Francis, London, 1923-1928.

JURAK, V., ORTOLAN, Ž., IVŠIĆ, T., HERAK, M., ŠUMANOVAC, F., VUKELIĆ, I. \& JUKIĆ, M. (2008): Geotehničko i seizmičko mikrozoniranje grada Zagreba pokušaji i ostvarenje. [Geotechnical and seismic microzonation of Zagreb: Attempts and realization - in Croatian].- In: RADIĆ, J. (ed.): Zbornik radova konferencije Razvitak Zagreba, Zagreb, Croatia, Feb. 1-2, 2008. SECON HDGK, Zagreb, 99-108.

KOMAC, M., HOLLEY, R., MAHAPATRA, P., VAN DER MAREL, H. \& BAVEC, M. (2015): Coupling of GPS/GNSS and radar interferometric data for a 3D surface displacement monitoring of landslides.- Landslides, 12/2, 241-257.

KRKAČ, M. (2015): Fenomenološki model gibanja klizišta Kostanjek na osnovi praćenja parametara klizanja [A phenomenological model of the Kostanjek landslide movement based on the landslide monitoring parameters - in Croatian].- Unpubl. PhD Thesis, Faculty of Mining, Geology and Petroleum Engineering, University of Zagreb, $210 \mathrm{p}$.

KRKAČ, M., MIHALIĆ, S., FERIĆ, P., PODOLSZKI, L., TOŠEVSKI, A. \& ARBANAS, Ž. (2013): Japanese-Croatian Project: Preliminary investigations of the Kostanjek landslide.- In: MARGTTINI, C., CANUTI, P. \& SASSA, K. (eds.): Proceedings of 2nd World Landslide Forum, 'Landslide Science and Practice', Vol. 6, Rome, Italy, Oct. 3-9, 2011. Springer, Germany, 385-390.

KRKAČ, M., MIHALIĆ ARBANAS, S., ARBANAS, Ž., BERNAT, S. \& ŠPEHAR, K. (2014a): The Kostanjek landslide in the City of Zagreb: Forecasting and protective monitoring.- In: LOLLINO, G., MANCONI, A., GUZZETTI, F., CULSHAW, M., BOBROWSKY, P. \& LUINO, F. (eds.): Proceedings of the XII IAEG Congress, Engineering Geology for Society and Territory, Vol. 5, Urban Geology, Sustainable Planning and Landscape Exploitation, Torino, Italy, Sept. 15-19, 2014. Springer, Heidelberg, 715-719.

KRKAČ, M., MIHALIĆ ARBANAS, S., NAGAI, O. \& ARBANAS, Ž. (2014b): The Kostanjek landslide - Monitoring system development and sensor network.- In: MIHALIĆ ARBANAS, S. \& ARBANAS, Ž. (eds.): Landslide and Flood Hazard Assessment, Proceedings of the 1st Regional Symposium on Landslides in the Adriatic-Balkan Region, Zagreb, Croatia, March 6-9, 2013. Croatian Landslide Group, Zagreb, 2014, 27-32. 
MAGDALENIĆ, A. (1967): Klizišta u sjeverozapadnoj Hrvatskoj [Landslides in the north-west Croatia - in Croatian].- In: Proceedings in Road Design and Construction in SFR Yugoslavia, 95-101.

MANSOUR, M.F., MORGENSTERN, N.R. \& MARTIN, D. (2010): Expected damage from displacement of slow-moving slides.- Landslides, 8, 117-131.

MCKEAN, J. \& ROERING, J. (2004): Objective landslide detection and surface morphology mapping using high-resolution airborne laser altimetry.- Geomorphology, 57/3-4, 331-351.

MIHALIĆ, S. (1998): Recommendations for landslide hazard and risk mapping in Croatia.- Geologia Croatica, 51/2, 195-204.

MIHALIĆ, S. \& ARBANAS, Ž. (2012): The Croatian-Japanese joint research project on landslides: Activities and public benefits.- In: SASSA, K., ROUHBAN, B., BRICEÑO, S., MCSAVENEY, M., HE, B. (eds.): Landslides: Global Risk Preparedness. Springer, Heidelberg, 333-349.

MIHALIĆ, S., BERNAT, S., HAMASAKI, E. \& GERBER, N. (2012): Historical landslides in the City of Zagreb: Landslide distribution analysis and 3D modeling of typical landslides in AdCALC3D.- In: OŽANIĆ, N., ARBANAS, Ž., MIHALIĆ, S., MARUI, H. \& DRAGIČEVIĆ, N. (eds.): Proceedings of the 2nd Workshop of the Croatian-Japanese SATREPS FY2008 Project, Rijeka, Croatia, Dec. 15-17, 2011. University of Rijeka, Rijeka, 2012, 122-125.

MIHALIĆ, S., MARUI, H., NAGAI, O., YAGI, H., MIYAGI, T. (2013): Landslide inventory in the area of Zagreb City: Effectiveness of using LiDAR DEM.In:MARGTTINI, C., CANUTI, P. \& SASSA, K. (eds.): Proceedings of 2nd World Landslide Forum, 'Landslide Science and Practice', Vol. 1, Rome, Italy, Oct. 3-9, 2011. Springer-Verlag, Germany, 155-162.

MIHALIĆ ARBANAS, S. \& ARBANAS, Ž. (2014): Landslides: A guide to researching landslide phenomena and processes.- In: GAURINA MEĐIMUREC, N. (ed.): Handbook of Research on Advancements in Environmental Engineering. Engineering Science Reference, Hershey PA, USA, 474-508.

MIHALIĆ ARBANAS, S., ARBANAS, Ž., BERNAT, S., KRKAČ, M., KALINIĆ, P., MARTINOVIĆ, K., FABRIS, N., SAJKO, J. \& ANTOLOVIĆ, A., (2013): Upravljanje kriznim situacijama uslijed pokretanja klizišta [Crisis management in case of landslide activations - in Croatian].- In: PERINIC, J. (ed.): Zbornik radova V. konferencije Hrvatske platforme za smanjenje rizika od katastrofa, Valbadon, Croatia, Oct. 17, 2013. Državna uprava za zaštitu i spašavanje, Zagreb, 151-164.

MIHALIĆ ARBANAS, S., BERNAT, S., FABIJANOVIĆ, S. \& ARBANAS, Ž. (2014): The analysis of historical landslide information from the area of the City of Zagreb and Primorsko-Goranska County.- In: MIHALIĆ ARBANAS, S. \& ARBANAS, Ž. (eds.): Landslide and Flood Hazard Assessment, Proceedings of the 1st Regional Symposium on Landslides in the Adriatic-Balkan Region, Zagreb, Croatia, March 6-9, 2013. Croatian Landslide Group, Zagreb, 91-96.

MIHALIĆ ARBANAS, S., KRKAČ, M., BERNAT, S. \& ARBANAS, Ž. (2012): Use of existing data in the City of Zagreb (Croatia, Europe) for the purpose of geoplanning.-- In: ZHOU, Y., CAI, J. \& STERLING, R. (eds.): Proceedings 'Advances in Underground Space Development', Singapore, November 7-9, 2012. Research Publishing, 465-477.

MIHALINEC, Z. \& ORTOLAN, Ž. (2008): Landslide 'Granice' in Zagreb (Croatia).In: CHEN, Z., ZHANG, J.-M., HO, K., WU, F.-Q. \& LI, Z.-K. (eds.): Proceedings of the 10th International Symposium on Landslides and Engineered Slopes, Xi' an, China, 30 June-4 July, 2008. CRC Press, 1587-1593.

MIKLIN, Ž., MLINAR, Ž., BRKIĆ, Ž., HEĆIMOVIĆ, I. \& DOLIĆ, M. (2007): Detaljna inženjerskogeološka karta Podsljemenske urbanizirane zone u mjerilu 1:5.000 (DIGK-Faza I) [Detailed engineering geological map of the Podsljeme urbanized zone in a scale of 1:5,000 (DIGK-Phase I) - in Croatian].- Croatian Geological Survey, Zagreb, Croatia.

NONVEILLER, E. (1964): Klizište u krutoj raspucaloj diluvijalnoj glini na Prekrižju u Zagrebu [Landslide in stiff fractured diluvial clay at the Prekrižje in Zagreb - in Croatian].- Građevinar, 2, 58-64.

NONVEILLER, E. (1987): Kliženje i stabilizacija kosina [Sliding and slope stabilization - in Croatian].- Školska knjiga, Zagreb, Croatia, 204 p.

ORTOLAN, Ž. (1996): Formiranje prostornog inženjerskogeološkog modela dubokog klizišta s više kliznih ploha (na primjeru klizišta Podsused) [Development of $3 D$ engineering geological model of deep landslide with multiple sliding surffaces (Example of the Podsused Landslide) - in Croatian].- Unpubl. PhD Thesis, Faculty of Mining, Geology and Petroleum Engineering, University of Zagreb, 236 p.

ORTOLAN, Ž. \& PLEŠKO, J. (1992): Repeated photogrammetric measurements at shaping geotechnical models of multi-layer-- Rudarsko-geološko-naftni zbornik, 4, 51-58.

ORTOLAN, Ž., JURAK, V., IVŠIĆ, T., HERAK, M. \& VUKELIĆ, I. (2008): Geotehničke okolnosti - rubni uvjet održivog razvitka "Podsljemenske urbanizirane zone [Geotechnical circumstances - boundary conditions for sustainable development of the 'Podsljeme Foothills Urbanized zone' - in Croatian].- In: RADIĆ, J. (ed.): Proceedings of the Conference 'Development of the Zagreb', Zagreb, Croatia, Feb. 1-2, 2008. SECON HDGK, Zagreb, 273-284.

PAVELIĆ, D., AVANIĆ, R., KOVAČIĆ, M., VRSALJKO, D. \& MIKNIĆ, M. (2003): An outline of the evolution of the Croatian part of the Pannonian Basin System.-
In: VLAHOVIĆ, I. \& TIŠLJAR, J. (eds.): 22nd IAS Meeting of Sedimentology, Opatija 2003 - Field Trip Guidebook. Institute of Geology, Zagreb, 155-161.

PETLEY, D.N., MANTOVANI, F., BULMER, M.N. \& ZANNONI, A. (2005): The use of surface monitoring data for the interpretation of landslide movement patterns.Geomorphology, 66/1-4, 133-147.

PODOLSZKI, L. (2014): Stereoskopska analiza klizišta i relativne opasnosti od klizanja na južnim obroncima Medvednice [Stereoscopic analysis of landslides and landslide susceptibility on the southern slopes of Medvednica Mt. - in Croatian].Unpbl. PhD Thesis, Faculty of Mining, Geology and Petroleum Engineering, University of Zagreb, $322 \mathrm{p}$.

POLAK, K. (1978): Neke značajke kvartarnih sedimenata istraživanih na primjeru klizišta Jelenovac kraj Zagreba [Some of the properties of the Quaternary deposits - Case study of the Jelenovac Landslide near Zagreb - in Croatian]. - Geološki vjesnik, 30/1, 151-165.

POLAK, K., KLEMAR, M., NEJKOVA, M., RADOŠEVIĆ, N., STEPAN, Z., MIROSLAV, M. \& KRIŽANIĆ, Z. (1979): Litološka obrada i kategorizacija terena prema stabilnosti tla obronaka Medvednice na području grada Zagreba [Lithological characterization and slope stability zonation of the hilly area of Medvenica Mt. at the area of the Zagreb city - in Croatian].-Geotehnika-Geoexpert, Zagreb, Croatia, $107 \mathrm{p}$.

POLAK, K., NONVEILLER, E., KLEMENČIĆ, B. \& LORENCIN, LJ. (1971): Studija sanacije klizišta Jelenovac u Zagrebu [Remediation study of the Jelenovac Landslide in Zagreb - in Croatian].- In: Proceedings of the 1st Yugoslav Symposium on Hydrogeology and Engineering Geology, Hercegnovi, Yugoslavia, May 4-8, 1971. 165-172.

RAZAK, K.A., STRAATSMA, M.W., VAN WESTEN, C.J., MALET, J.-P. \& DE JONG, S.M. (2011): Airborne laser scanning of forested landslides characterization: Terrain model quality and visualization.- Geomorphology, 126, 186-200.

REUTEBUCH, S.E., MCGAUGHEY, R.J., ANDERSON, H.E. \& CARSON, W.W. (2003): Accuracy of a high-resolution LiDAR terrain model under a conifer forest canopy.- Canadian Journal of Remote Sensing, 29, 527-535.

SANTANGELO, M., CARDINALI, M., ROSSI, M., MONDINI, A.C. \& GUZZETTI, F. (2010). Remote landslide mapping using a laser rangefinder binocular and GPS.Natural Hazards and Earth System Sciences, 10/12, 2539-2546.

SASSA, K. \& HE, B. (2013): TXT-tool 3.081-1.2 Landslide dynamics.- In: SASSA, K., HE, B., MCSAVENEY, M. \& OSAMU, N. (eds.): ICL Landslide Teaching Tools.International Consortium on Landslides, Kyoto, Japan, 215-237.

SCHULZ, W.H. (2007): Landslide susceptibility revealed by LIDAR imagery and historical records, Seattle, Washington.- Engineering Geology, 89, 67-87.

SHAN, J. \& TOTH, C.K. (2009): Topographic laser ranging and scanning: Principles and processing.-CRC Press, Taylor and Francis Group, Boca Raton, Florida, 590p.

SOKOLIĆ, Ž., HRŠAK, A. \& VLAIĆ LONČAR, A. (2006): Negativni utjecaji nekontroliranog odlaganja otpada na području Podsljemenske zone u Zagrebu [Negative influence of uncontrolled waste disposals in the area of hilly zone of the Zagreb City - in Croatian].- In: MILANOVIĆ, Z. (ed.): Proceedings of the 9th International Symposia of the Waste Management, Zagreb, Croatia, Nov. 15-18, 2006. $1-22$.

STANIĆ, B. \& NONVEILLER, E. (1996): The Kostanjek landslide in Zagreb. - Engineering Geology, 42, 269-283.

ŠAGUD, D. (2015): Statistička analiza inventara klizišta Podsljemenske zone iz 1979. godine [Statistical analysis of landslide inventory of the Podsljeme area from 1979 - in Croatian].- Unpubl. MS Thesis, Faculty of Mining, Geology and Petroleum Engineering, University of Zagreb, $47 \mathrm{p}$.

ŠIKIĆ, V. (1967): Inženjerska geologija Zagreb - sjever i jug [Engineering geology Zagreb - north and south - in Croatian] - Croatian Geological Survey, Zagreb, $152 \mathrm{p}$.

ŠIKIĆ, K. (1995): Geološki vodič Medvednice [A geological guide to Medvednica Mt. - in Croatian].- Croatian Geological Survey and INA-Industrija nafte, Zagreb, $199 \mathrm{p}$.

ŠIKIĆ, V., VILJEVAC, Ž. \& BASTALIĆ, N. (1984): Nastanak klizišta na Kajfešovom bregu u Zagrebu [Origin of the landslides at the Kajfeš hill in Zagreb - in Croatian].- In: Proceedings of the 8th Yugoslav. Symposia on Hydrogeology and Engineering Geology, Budva, Yugoslavia, September 18-22, 1984, 213-219.

TOFANI, V., RASPINI, F., CATANI, F. \&, CASAGLI, N. (2013): Persistent Scatterer Interferometry (PSI) technique for landslide characterization and monitoring.- Remote Sensing, 5, 1045-1065.

VAN DEN EECKHAUT, M., POESEN, J., VERSTRAETEN, G., VANACKER, V., NYSSEN, J., MOEYERSONS, J., VAN BEEK, L.P.H. \& VANDEKERCKHOVE, L. (2007): Use of LIDAR-derived images for mapping old landslides under forest.- Earth Surface Processes and Landforms, 32, 754-769.

VAN WESTEN, C.J., CASTELLANOS ABELLA, E.A. \& SEKHAR, L.K. (2008): Spatial data for landslide susceptibility, hazards and vulnerability assessment: An overview.- Engineering Geology, 102, 112-131.

VRSALJKO, D., PAVELIĆ, D., MIKNIĆ, M., BRKIĆ, M., KOVAČIĆ, K., HEĆIMOVIĆ, I., HAJEK-TADESSE, V., AVANIĆ, R. \& KURTANJEK, N. (2006): Middle Miocene (Upper Badenian/Sarmatian) palaeoecology and evolution of the environments in the area of Medvednica Mt. (North Croatia).- Geologia Croatica, 59/1, 51-63. 